\title{
Unceasing Animosities and the Public Tranquility: Political Market Failure and the Scope of the Commerce Power
}

\author{
Adam Badawi $\dagger$
}

TABLE of Contents

Introduction.

I. The Historical Development of the Commerce Clause .................. I337

A. The Original Purpose of the Commerce Clause

B. The Historical Development of the Supreme Court's

Commerce Clause Jurisprudence

1. Gibbons v. Ogden.

2. The Progressive Era Court

3. The New Deal Court 1342

4. The Modern Era ......................................................... 1344

5. United States v. Lopez ..................................................... 1345

6. United States v. Morrison............................................... 1347

II. The Scope of the Commerce Clause: Identifying the Flaws of the Political Safeguards and Narrow Scope Approaches

A. The Political Safeguards Approach to the Commerce

Clause: Allowing Congress Broad Powers

B. The Narrow Scope Approach to the Commerce Clause:

Limiting the Reach of Congress

Copyright $\odot 2003$ California Law Review, Inc. California Law Review, Inc. (CLR) is a California nonprofit corporation. CLR and the authors are solely responsible for the content of their publications.

$\dagger \quad$ J.D., School of Law, University of California, Berkeley (Boalt Hall), 2003; Ph.D. Candidate (expected 2004), Jurisprudence \& Social Policy Program, University of California, Berkcley. Law clerk to the Hon. Michael W. McConnclI, Tenth Circuit Court of Appeals, 2004-05. I am indebted to Robert Cooter and Robert Post for co-teaching the seminar that inspired this Comment and for providing extremely helpful comments on this piece. I also would like to thank Philip Frickey, Neil Siegel, John Manning, and Jeff Bleich for their thorough and insightful suggestions on this piece. I want to cxpress my gratitude to Heather Weaver, Karen Petroski, and the staff of the California Law Review for providing invaluable editorial commentary and assistance. All mistakes are my own. Finally, I dedicate this Comment to my parents, Sam and Donna, and to my brothers, Rick and Ramsey, for their unwavering support. The terms "unceasing animosities" and "public tranquillity" come from Madison's justification for the Commerce Clause in ThE FEderalist No. 42 (James Madison). See infra note 20 and accompanying text. 
C. Weaknesses of the Two Traditional Approaches to Commerce Clause Scholarship .............................................. 1352

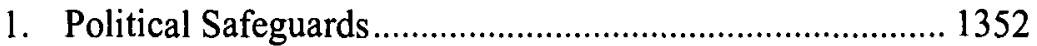

2. Narrow Scope .................................................................. 1353

III. Public Choice Theory, Political Market Failure, and the Commerce Power

A. Introduction to Public Choice Theory and Political Market Failure

B. Political Market Failure: The Public Choice Argument for Occasional Centralization

1. Externalities.

2. Holdouts 1360

C. Political Market Failure and the Dormant Commerce Clause 1362

D. Regulatory Warfare as a Holdout Problem 1364

IV. Political Market Failure Theory Applied to the Commerce Clause

A. The Infirmities of Lopez ...................................................... 1366

B. Jones v. United States ............................................................ 1367

C. Solid Waste Agency v. United States Army Corps of Engineers 


\title{
Unceasing Animosities and the Public Tranquility: Political Market Failure and the Scope of the Commerce Power
}

\author{
Adam Badawi
}

Curtailing the economic chaos created by a dearth of centralized power was a prominent motivation for including the Commerce Clause among the enumerated powers of Congress. The Founders, particularly Madison and Hamilton, recognized that giving near plenary power to the federal government to regulate commerce would reduce the incentive for states to engage in the series of regulatory retaliations that was crippling. the early Republic's economy. This Comment argues that this animating purpose of the Commerce Clause was a solution to what public choice scholars would now recognize as a collective action problem. However, the collective action logic that partially motivated the Commerce Clause is largely absent both from the United States Supreme Court's Commerce Clause jurisprudence and the more successful academic approaches to federalism. This Comment uses the tools of public choice analysis to develop a theory of political market failure, which expands on the collective action problem identified by the Framers. This political market failure analysis suggests that externalities and holdouts create a justification for the exercise of centralized power. The standard articulated by the Court in United States v. Lopez does not clearly incorporate these concerns. This Comment discusses the subsequent cases of Jones v. United States and Solid Waste Management v. Army Corps of Engineers to suggest how externalities and holdouts might play a role in post-Lopez Commerce Clause jurisprudence.

\section{INTRODUCTION}

The lack of centralized power in the Articles of Confederation sparked economic chaos in the United States' developing years. Fueled by their own self-interest, the states helped create this imbroglio by engaging in a destructive cycle of regulatory warfare that collectively crippled the ability to make and ship goods. ${ }^{1}$ By vesting the commerce power in the new

1. At least one scholar has suggested that the inability of the states to regulate commerce was the primary motivating factor behind the Constitution. See Lino A. Graglia, How the Constitution Disappeared, in 1NTerpreting the Constitution: The Debate over Original Intent 35, 42 
Congress, the Founders provided a mechanism to eliminate this disastrous system of state duties and taxes. ${ }^{2}$ Since the Founding, commerce has evolved significantly from simple transactions between agrarian yeomen and shipping merchants to a technologically sophisticated national market. The commerce power likewise has evolved to accommodate the changes in the American economic system. State self-interest, however, remains a persistent regulatory motivation. This Comment argues that an original purpose of the Commerce Clause-preventing state regulatory self-interest from creating collective action problems that leave everyone worse offshould play a more prominent role in shaping Commerce Clause doctrine.

Defining what qualifies as interstate commerce has been a perennial problem in the Supreme Court's Commerce Clause jurisprudence. For nearly sixty years, the Court allowed congressional regulation of activities that had any putative connection to interstate commerce. ${ }^{3}$ However, given the increasingly large and pervasive national market, few, if any, activities now do not have a colorable connection to interstate commerce. Thus, this standard essentially eliminated judicial review under the Commerce Clause. Only recently, with its decision in United States v. Lopez ${ }^{4}$ has the Court begun to restrict Congress's Commerce Clause power and to limit the definition of "interstate commerce."

The Court's division over this issue in Lopez reflects the two traditional schools of thought regarding the scope of the Commerce Clause: the political safeguards of federalism thesis and the narrow scope approach. First articulated by Herbert Wechsler ${ }^{5}$ and later elaborated by Jesse

(Jack N. Rakove ed., 1990) ("The primary motivating force for the creation of a stronger national government was the felt need of a central authority to remove state-imposed obstacles to interstate trade.").

2. During the Federal Convention, an initial proposal for defining the scope of the legislature's power bluntly identified the problems caused by lack of centralization. On July 17, 1787, Gunning Bedford moved to amend one section of the working document to read: "[Congress may] legislate in all cases for the general interests of the Union, and also in those to which the States are separately incompetent, or in which the harmony of the [U]nited States may be interrupted by the exercise of individual Legislation." James Madison, The Debates in the Federal Convention of 1787 Which Framed the Constitution of the United States of America 265 (photo. reprint 1999) (Gaillard Hunt \& James Brown Scott eds., 1920) (internal quotation marks omitted). See also discussion of The Federalist Nos. 22, 42 infra Part 1.A.

3. Between roughly 1938 and 1995 , the Court was extremely reluctant to strike down federal laws for exceeding Congress's Commerce Clause power. This time frame is bounded by NLRB v. Jones \& Laughlin Steel Corp., 301 U.S. 1 (1937), in which the Court upheld the National Labor Relations Act as a lawful congressional exercise of the commerce power, and United States v. Lopez, 514 U.S. 549 (1995), in which the Court struck down the Gun-Free School Zones Act (GFSZA) as outside the scope of the Commerce Clause. The Court did strike down a federal law in National League of Cities $v$. Usery, 426 U.S. 833 (1976), but repudiated this decision nine years later in Garcia v. San Antonio Metropolitan Transit Authority, 469 U.S. 528 (1985). See discussion infra Part 1.B.4.

4. 514 U.S. 549 (1995).

5. See Herbert Wechsler, The Political Safeguards of Federalism: The Role of the States in the Composition and Selection of the National Government, 54 CoLuM. L. Rev. 543 (1954) (arguing that 
Choper, ${ }^{6}$ the political safeguards thesis posits that the scope of the Commerce Clause should be decided through the political process rather than through judicial intervention. Although the Supreme Court explicitly cmbraced this theory in its 1985 opinion in Garcia v. San Antonio Metropolitan Transit Authority, ${ }^{7}$ many scholars and judges have identified major problems with the political safeguards approach to federalism and to the Commerce Clause in particular. First, the theory departs from the principles of state sovereignty and limited centralized government inherent in the Constitution's grant of limited powers to Congress under Article I. ${ }^{8}$ Second, this approach undermines the ability of states to vary policies in order to suit the preferences of their citizens and to attract potential citizens by offering laws that are more appealing than those of neighboring states. ${ }^{9}$ Finally, this framework ignores an underlying purpose of the Commerce Clause, which is to permit the exercise of centralized power to limit interstate economic balkanization and other types of internecine regulatory warfare $^{10}$

Opponents of the political safeguards theory offer some valid critiques but too often advocate a narrow scope approach to the Commerce Clause as the proper alternative." Advocates of the narrow scope approach argue that courts should use historically based definitions of "commerce" to limit congressional exercise of the commerce power. ${ }^{12}$ Like the political safeguards thesis, however, the narrow scope theory is problematic. First, the meaning of the term "commerce" at the time of the Framing is historically indeterminate and uncertain. ${ }^{13}$ Second, the narrow scope theorists'

judicial review of the Commerce Clause is not necessary because states can represcnt their intcrests in Congress).

6. See Jesse H. Choper, Judiclal Review and the National Political Process 175-76 (1980).

7. 469 U.S. 528, 550-51, $551 \mathrm{n} .11$ (1985) (citing the works of Wechsler and Choper in noting that "the Federal Government was designed in large part to protect the states from overreaching by Congress").

8. This theme is common in opinions by justices sympathetic to federalism. See, e.g., Lopez, 514 U.S. at 575-83 (Kennedy, J., concurring); F.E.R.C. v. Mississippi, 456 U.S. 742, 787-91 (1982) (O'Connor, J., concurring in part and dissenting in part); Nat'l League of Cities v. Usery, 426 U.S. 833 , 842-45 (1976). For an academic defonse of this position, see Richard A. Epstein, Exit Rights Under Federalism, 55 LAW \& CONTEMP. ProBs. 147 (1992) (arguing that federalism curbs governmental power because individuals can move from state to state).

9. See infra Part 111 .

10. See infra Part III.

11. Advocates of this approach include Randy E. Barnett, The Original Meaning of the Commerce Clause, 68 U. CHI. L. REv. 101 (2001); Raoul Berger, Judicial Manipulation of the Commerce Clause, 74 TEx. L. REv. 695 (1996); Richard A. Epstein, The Proper Scope of the Commerce Power, 73 VA. L. REv. 1387 (1987). See discussion of the narrow scope approach infra Part 11.B.

12. Bamett, supra note 11; Berger, supra note 11; Epstein, supra note 11.

13. See Grant S. Nelson \& Robert J. Pushaw, Jr., Rethinking the Commerce Clause: Applying First Principles to Uphold Federal Commercial Regulations But Preserve State Control Over Social Issues, 85 lowa L. REV. 1, 1-50 (1999). 
atomistic, originalist interpretation of the meaning of "commerce" ignores the valuable functionalist and evolutive lessons taught by the political safeguards approach. By focusing exclusively on what the word "commerce" may have meant in the eighteenth century, the narrow scope approach, like the political safeguards approach, ignores an underlying purpose of the Commerce Clause-preventing states from engaging in crippling regulatory warfare.

This Comment argues that insights from public choice theory can, and should, guide a doctrinal standard that effectuates the animating purpose of the Commerce Clause. Public choice theory analyzes the allocation of power among centralized and decentralized governmental institutions. This approach, which assumes that states act in the interests of their own citizens, advocates the use of centralized power when the political markets of decentralized states fail. Such political market failures occur when the regulatory action or inaction of one state affects the well-being of other states.

Correcting these political market failures was an original purpose of the Commerce Clause. A Commerce Clause doctrine that uses the tools of public choice theory to analyze political market failure remains faithful to this original purpose while accommodating the sea changes in American commerce since the Founding. Such a standard, based on a theory of political market failure, also aligns Commerce Clause doctrine with the Court's eurrent Dormant Commerce Clause principles, which evince a deep suspicion of states' willingness to act outside their self-interest. Moreover, a theory of political market failure also helps to answer some of the difficult questions left unresolved in Lopez. ${ }^{14}$

To lay a foundation for this application of the theory of political market failure, Part I traces the historical development of the Commerce Clause and its related jurisprudence. Part II presents the two traditional academic approaches to this jurisprudence: the political safeguards and narrow scope theories. It details their weaknesses and their failure to eomport with the skepticism regarding state political action that originally gave rise to the Commerce Clause. Part III argues that public choice theory has built upon James Madison's and Alexander Hamilton's justifications for the Commerce Clause and can provide a coherent theory to distinguish between the proper and improper centralization of political power on the basis of political market failure. Finally, Part IV applies the theory of political market failure to two recent Supreme Court cases, Jones $v$. United

14. The literature on Lopez is vast. For a small sample of the critical literature, see, for example, Daniel A. Farber, The Constitution's Forgotten Cover Letter: An Essay on the New Federalism and the Original Understanding, 94 МicH. L. Rev. 615 (1995); Philip P. Frickey, The Fool on the Hill: Congressional Findings, Constitutional Adjudication and United States v. Lopez, 46 CASE W. Res. L. REv. 695 (1996); Donald H. Regan, How to Think About the Federal Commerce Power and Incidentally Rewrite United States v. Lopez, 94 МicH. L. REv. 554 (1995). 
States ${ }^{15}$ and Solid Waste Agency v. Army Corps of Engineers, ${ }^{16}$ in which the Court declined to apply the Lopez standard and, in so doing, sidestepped opportunities to employ a political market failure theory to clarify the scope of the commerce power.

The Historical Development of the Commerce Clause

The Commerce Clause is the third of the enumerated powers granted to Congress in Article I of the Constitution. It vests Congress with the power " $[t] 0$ regulate Commerce with foreign Nations, and among the several States, and with the Indian Tribes."17 This Part traces the history of the Commerce Clause by recounting the rationale for its inclusion in the Constitution and the major doctrinal trends in the Court's Commerce Clause jurisprudence. This Part explains the justifications Madison and Hamilton advanced for the Commerce Clause and argues that the Founders recognized that denying the federal government sufficient centralized power would lead to collective action problems. This Part then demonstrates that this underlying purpose of the Commerce Clause has had little place in the evolution of the Court's Commerce Clause doctrine.

\section{A. The Original Purpose of the Commerce Clause}

The Framers included the Commerce Clause in the Constitution in part to prevent the economic balkanization that often accompanies a weak or decentralized federal government. ${ }^{18}$ The Articles of Confederation afforded too little power to the centralized government, especially with respect to commerce, resulting in economic divisions among the states. ${ }^{19}$ James Madison explained why the absence of a strong federal power to regulate commercial activity was problematic and how the dilemma could be resolved:

The defect of power in the existing confederacy, to regulate the commerce between its several members, is in the number of those which have been clearly pointed out by experience.... [I]t may be added, that without [the Commerce Clause], the great and essential power of regulating foreign commerce, would have been ineomplete and ineffectual. A very material object of this power was the relief of the states which import and export through other states, from the improper contributions levied on them by the latter. Were these at liberty to regulate the trade between state and state, it

15. 529 U.S. $848(2000)$.

16. 531 U.S. 159 (2001).

17. U.S. Const. art. $1, \S 8, \mathrm{cl} .3$.

18. See Nelson \& Pushaw, supra note 13 , at $22-25$ (diseussing the commercial chaos at the time of the Framing).

19. See id.; see also supra note 2 . 
must be foreseen, that ways would be found out, to load the articles of import and export, during the passage through their jurisdiction, with duties which would fall on the makers of the latter, and the consumers of the former. We may be assured, by past experience, that such a practice would be introduced by future contrivances; and both by that and a common knowledge of human affairs, that it would nourish unceasing animositics, and not improbably terminate in serious interruptions of the public tranquillity. ${ }^{20}$

The last sentence of Madison's passage contains an animating rationale of the Commerce Clause: Where the states, in pursuit of their selfinterest, will produce a situation that leaves everyone worse off-in Madison's words, where "unceasing animosities" will result in "interruptions of the public tranquillity" Congress jurisdiction under the Commerce Clause. Indeed, in this passage Madison identifies both the existence of, and one solution to, collective action problems more than a century and a half before Garrett Hardin initiated academic inquiry into the phenomenon. ${ }^{22}$

Hamilton provided a similar justification for the Commerce Clause in The Federalist No. 22:

The interfering and unneighborly regulations of some states, contrary to the true spirit of the union, have, in different instances given just cause of umbrage and complaint to others; and it is to be feared that examples of this nature, if not restrained by a national control, would be multiplied and extended till they become not less serious sources of animosity and discord, than injurious impediments to the intercourse between the different parts of the confederacy.... [W]e may reasonably expect from the gradual conflicts of state regulations, that the citizens of each would at length come to be considered and treated by the others in no better light than that of foreigners and aliens. ${ }^{23}$

Both of these passages evince skepticism about allowing states to act on their own. The Framers feared that states would be unable or unwilling to take into account the welfare of those living outside their borders and predicted that economic balkanization and regulatory wars would result. In response to these concerns, the Framers included the Commerce Clause in enumerating the powers of Congress. As this Comment later discusses, however, this original purpose is not reflected in the Court's post-Lopez

20. The Federalist No. 42, at 195-96 (James Madison) (Masters, Smith \& Co. 1857).

21. Id. at 196.

22. See Garrett Hardin, The Tragedy of the Commons, 162 ScI. 1243 (1968). Hardin analyzed the incentives of herdsmen to maintain a common field. He concluded that if multiple herdsmen were using the same field, each would have little incentive to maintain it, because no herder would reap the entire benefits of his own labor. Hardin concluded that "[f]reedom in a commons brings ruin to all." $I d$. at 1244. See also discussion of rent-seeking and the Dormant Commerce Clause infra Part 111.C.

23. The Federalist No. 22, at 97-98 (Alexander Hamilton) (Masters, Smith \& Co. 1857). 
Commerce Clause doctrine, the political safeguards theory, or the narrow scope approach. ${ }^{24}$ By contrast, the notion that states will pursue only the interests of their citizens is a key tenet of public choice theory.

\section{B. The Historical Development of the Supreme Court's Commerce Clause Jurisprudence}

\section{Gibbons v. Ogden}

Gibbons v. Ogden, the first major case to address the scope of the Commerce Clause, involved a challenge to a New York law granting an exclusive franchise for steamships passing between New York and New Jersey. ${ }^{25}$ Writing that Congress could regulate "commerce which concerns more States than one," ${ }^{, 26}$ the Court held that navigation between states was within the scope of the Commerce Clause and that a 1793 federal law licensing ships preempted the state law. ${ }^{27}$ Chief Justice Marshall wrote for the majority:

If, as has always been understood, the sovereignty of Congress, though limited to specified objects, is plenary as to those objects, the power over commerce with foreign nations, and among the several States, is vested in Congress as absolutely as it would be in a single government, having in its constitution the same restrictions on the exercise of the power as are found in the constitution of the United States. ${ }^{28}$

Marshall noted, however, that while the power of Congress was plenary over objects within the scope of the Commerce Clause, Congress had no power over activity outside the scope of the Commerce Clause, which he defined as "the exclusively internal commerce of a State." 29

\section{The Progressive Era Court}

Commerce Clause doctrine after Gibbons and before the passage of the Interstate Commerce and Sherman Acts was largely unremarkable. ${ }^{30}$ But the passage of these two bills in 1887 and 1890 marked the emergence of an increasingly national market as well as a disposition to regulate the

24. See infra Parts II.A-C.

25. Gibbons v. Ogden, 22 U.S. (9 Wheat.) I, I-2 (1824).

26. Id. at 194.

27. Id. at 2, 190-91, 213-I7.

28. Id. at 197 .

29. Id. at 195.

30. For a discussion of this period, see Laurence H. Tribe, American Constitutional Law $\S 5-4$, at $808 \&$ n.6 (3d ed. 2000). Tribe states that the cases of this era "reflect inconsistent doctrinal themes." Id. As cases that support broader exercise of congressional power under the Commerce Clause, he cites United States v. Marigold, 50 U.S. (9 How.) 560 (I850), and The Daniel Ball, 77 U.S. (10 Wall.) 557 (1871). TRIBE, supra, at 808-09 n.6. As early cases limiting the scope of the commerce power, he cites United States v. Dewitt, 76 U.S. (9 Wall.) 41 (1870), and the Trade-Mark Cases, 100 U.S 82 (1879). TRIBE, supra, at 809 n.6. 
market at the federal level. In addition, the wide grant of power to the Interstate Commerce Commission in these bills made the scope of the Commerce Clause a more pressing concern. ${ }^{31}$ Between 1887 and 1937, the Court took a more restrictive approach to Congress's commerce power than Marshall had in Gibbons. ${ }^{32}$

United States v. E.C. Knight Co., the definitive Commerce Clause case of the era, exemplifies this approach. ${ }^{33}$ E.C. Knight, which tested the ability of the federal government to enforce the Sherman Act, involved a challenge to a New Jersey sugar-manufacturing corporation's attempt to acquire four Pennsylvania sugar-manufacturing firms. ${ }^{34}$ The Court held that the merger itself was not part of interstate commerce and that the transaction had "no direct relation to commerce." 35 In reaching this holding, Chief Justice Fuller distinguished between manufacturing and commerce, a dichotomy that would influence the Court until the New Deal: "The fact that an article is manufactured for export to another State does not of itself make it an article of interstate commerce, and the intent of the manufaeturer does not determine the time when the article or product passes from the control of the State and belongs to commerce." ${ }^{36}$

The Court repeatedly applied the manufacturing-commerce distinction throughout the Progressive Era, most notably in Hammer v. Dagenhart, in which a closely divided panel struck down a federal statute prohibiting the shipment of goods manufactured with child labor. ${ }^{37}$ Writing for the majority, Justice Day steadfastly applied the distinction developed in E.C. Knight. ${ }^{38}$ The Court held that, because the statute attacked the manner of manufacture rather than the transport of the goods, it fell outside the scope of the Commerce Clause. In a vociferous dissent, Justice Holmes characterized the distinetion as unworkable and theoretically hollow:

The act does not meddle with anything belonging to the States. They may regulate their internal affairs and their domestic commerce as they like. But when they seek to send their products across the state line they are no longer within their rights. If there were no Constitution and no Congress their power to cross the line would depend upon their neighbors. Under the Constitution such

31. See TriBE, supra note 30 , at 808 .

32. During this era, the Court held that Congress had exceeded its commerce power on eight occasions. See id. at $810 \mathrm{n} .8$ (listing the cases). There is some debate as to the impact of these holdings. Compare TR1BE, supra note $30, \S 5-4$, at $810 \mathrm{n} .8$ (arguing that while the cases are few in number, they served as a thrcat to lower courts and to Congress), with Robcrt Post, Federalism in the Taft Court Era: Can It Be "Revived"?, 51 DuKE L.J. 1513 (2002) (arguing that these cases display a growing acceptance of a national market).

33. 156 U.S. 1 (1895).

34. Id. at 9 .

35. Id. at $16-17$.

36. Id. at 13 .

37. 247 U.S. 251 (1918) (5-4 decision).

38. Id. at 271-72. 
commerce belongs not to the States but to Congress to regulate. It may carry out its views of public policy whatever indirect effect they may have upon the activities of the States. Instead of being encountered by a prohibitive tariff at her boundaries the State encounters the public policy of the United States which it is for Congress to express. The public policy of the United States is shaped with a view to the benefit of the nation as a whole. ${ }^{39}$

The Court, however, was not always assiduous about applying the E.C. Knight standard during this era. In Champion v. Ames, the Court upheld a federal statute prohibiting the transport of lottery tickets across state lines. ${ }^{40}$ As both justices ${ }^{41}$ and scholars ${ }^{42}$ have pointed out, however, very little distinguishes Knight from Champion. Both statutes attacked the character of the good at issue rather than its transport. Justice Harlan found that the Champion statute was permissible because it was a suitable regulation of "public morals," ${ }^{43}$ but it remains unclear why the regulation of public morals related to gambling is a permissible exercise of the commerce power, whereas regulation of the public morals related to child labor is not. These holdings demonstrate the doctrinal disarray of Knight and its progeny as well as the pitfalls of using imprecise semantic distinctions to govern the scope of the commerce power.

Another line of cases in the Progressive Era found that some types of intrastate regulation were permissible uses of the commerce power. The Shreveport Rate Cases involved the authority of the Interstate Commerce Commission to regulate railroad fares for intrastate travel by railroads that also ran interstate trains. ${ }^{44}$ The Court held that Congress, either directly or through delegation to a federal agency, may regulate the instruments of interstate commerce..$^{45}$ The Court emphasized the plenary power of Congress to regulate activity falling within the scope of the commerce power: "The fact that carriers are instruments of intrastate commerce, as well as of interstate commerce, does not derogate from the complete and paramount authority of Congress over the latter. ${ }^{\$ 46}$ Given the willingness of the Progressive Era Court to overturn federal legislation, this holding was a significant expansion of the Commerce Clause.

39. Id. at 281 (Holmes, J., dissenting).

40. 188 U.S. 321 (1903).

41. Holmes castigated the Hammer majority for attempting to reconcile its holding with Champion. Hammer, 247 U.S. at 277-78 (Holmes, J., dissenting).

42. Tribe calls the attempt to distinguish Hammer from Champion "transparently unconvincing." See TRlBE, supra note $30, \S 5-5$, at 828 n. 10 .

43. Champion, 188 U.S. at 356.

44. 234 U.S. 342 (1914).

45. Id. at 351 .

46. Id. 


\section{The New Deal Court}

The fissures in Commerce Clause jurisprudence created by the Shreveport Rate Cases foreshadowed the dramatic changes in the scope of the commerce power made by the New Deal Court. The election of Franklin D. Roosevelt in 1932 and his ambitious New Deal agenda created significant friction between the political branches and the Supreme Court. The mandate of FDR's 1936 reelection, the prospect of court packing, and the sympathy of some judges for a stronger federal government produced a significant shift in the Court's approach to constitutional law in general and the commerce power in particular. ${ }^{47}$

The first major case in this new era, NLRB v. Jones \& Laughlin Steel Corporation, ${ }^{48}$ involved a challenge to the National Labor Relations Act. ${ }^{49}$ The law eliminated at-will employment in favor of collective bargaining where a union had the support of a majority of employees. ${ }^{50}$ The text of the statute pushed the boundaries of existing Commerce Clause jurisprudence by authorizing jurisdiction over commerce and cases "affecting commerce." 51 The statute defined "affecting commerce" as "in commerce, or burdening or obstructing commerce or the free flow of commerce, or having led or tending to lead to a labor dispute burdening or obstructing commerce or the free flow of commerce." 52 Abandoning the prior era's manufacturing-commerce distinction, the Court upheld the statute and expressed a willingness to take a functional and empirical approach to Commerce Clause jurisprudence. The Court pledged that future evaluation of "interferences with... commerce" would "not ignore actual experience." 53 This ruling sparked a new jurisprudential trend toward examining the effect of a given activity on commerce instead of merely considering the physical attributes of the regulated action ${ }^{54}$ and resulted in a rapid doctrinal shift that put almost nothing beyond the reach of congressional regulation. ${ }^{55}$

By the New Deal era, the national market was sufficiently broad to support a finding that almost any activity had a colorable connection to

47. See Gerald Gunther \& Kathleen M. Sullivan, Constitutional Law 183-96 (13th ed. 1997).

48. 301 U.S. 1 (1937).

49. Ch. 372, 49 Stat. 449 (1935) (current version at 29 U.S.C. $\$ \$ 151-169(2000)$ ).

50. See 29 U.S.C. $\$ 158(\mathrm{a})(5)$.

51. 29 U.S.C. $\$ 152(7)$.

52. Id.

53. Jones \& Laughlin, 301 U.S. at 42.

54. See TriBE, supra note $30, \S 5-4$, at 812 .

55. For example, in United States v. Darby, 312 U.S. 100 (1941), the Court held that Congress could regulate intrastate activity that affected other states. To justify this substantial broadening of the scope of the commerce power, the Court invoked the Necessary and Proper Clause, holding that the regulation of state activity affecting interstate commerce was necessary to further the goals of the Commerce Clause, even if the activity regulated took placc only within the state. $I d$. at 118-20. 
interstate commerce. Examining activities' effects, rather than their character, to determine their role in interstate commerce undermined use of the Commerce Clause to invalidate federal statutes. Wickard $v$. Filburn perhaps best demonstrates this dramatic shift in the balance of power between Congress and the states. ${ }^{56}$ At issue in Wickard was the authority of the Secretary of Agriculture to penalize a farmer for exceeding the permitted quota of wheat, where the excess wheat was for the farmer's own consumption..$^{57}$ In upholding the Secretary's authority to levy the fine, the Court solidified its policy of according Congress extreme deference with respect to the boundaries of the commerce power. The Court ruled that

[t]he commerce power is not confined in its exercise to the regulation of commerce among the states. It extends to those activities intrastate which so affect interstate commerce, or the exertion of the power of Congress over it, as to make regulation of them appropriate means to the attainment of a legitimate end, the effective execution of the granted power to regulate interstate commerce. $^{58}$

Hence, the Court concluded, "the reach of that power extends to those intrastate activities which in a substantial way interfere with or obstruct the exercise of the granted power." 59

The Court observed that the aggregate effect of homegrown wheat on the national market for wheat was significant enough to place the activity at issue within the scope of Congress's commerce power. ${ }^{60} \ln$ his opinion for the majority, Justice Jackson emphasized the low barrier to lawful exercise of the eommerce power:

The conflicts of economic interest between the regulated and those who advantage by it are wisely left under our system to resolution by the Congress under its more flexible and responsible legislative process. Such conflicts rarely lend themselves to judicial determination. And with the wisdom, workability, or fairness, of the plan of regulation we have nothing to do. ${ }^{61}$

This refusal to inquire into legislative motives and propriety with respect to the preemption of state regulation discouraged any commerce power challenges to federal regulation.

The trend of deference to Congress exemplified by Wickard v. Filburn continued through the Warren Court era, during which the Court never found that Congress had exceeded the bounds of the commerce power. Congress was cognizant of this deference and expanded its use of the

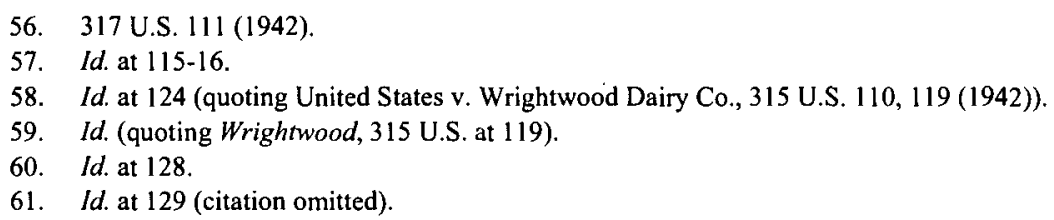

61. Id. at 129 (citation omitted). 
commerce power to legislate in areas such as civil rights ${ }^{62}$ and criminal activity. ${ }^{63}$

\section{The Modern Era}

The first break in the Court's deference to Congress's commerce power appeared in National League of Cities $v$. Usery. ${ }^{64}$ This case involved an amendment to the Fair Labor Standards Act (FLSA) that made the statute's minimum wage provisions applicable to state and local governments. ${ }^{65}$ A narrow majority of the Court held that the FLSA, when applied to state and local governments, exceeded the scope of the commerce power. ${ }^{66}$ However, in reaching this conclusion the Court articulated a problematic standard that it would repudiate less than a decade later. The Court determined that Congress had no authority, by virtue of the Tenth Amendment, to regulate the states as states ${ }^{67}$ Overruling its decision in Maryland $v$. Wirtz ${ }^{68}$ in which it had held that the FLSA was lawful as applied to state-run hospitals and schools, ${ }^{69}$ the National League Court held that when a federal statute interferes with the traditionally "integral governmental functions" of a state or local government, it is regulating the states as states. ${ }^{70}$

The Court explicitly overruled this standard only nine years later in Garcia v. San Antonio Metropolitan Transit Authority. ${ }^{71}$ In this case, the Court assailed the historical standard used in National League as anathema to federalism and wrote that distinguishing between essential and nonessential government functions is a hopeless task. ${ }^{72}$ Due to the doctrinal morass produced by the "traditional governmental function" standard, ${ }^{73}$ the Court returned to the New Deal substantial effects test. ${ }^{74}$

Unstated in the Garcia opinion is the substantial disagreement between the justices on matters of federalism. The National League and

62. See Heart of Atlanta Motel, Inc. v. United States, 379 U.S. 24l, 256 (1964) (upholding the enforcement of Title 11 of the Civil Rights Act of 1964, which prohibits racial discrimination in establishments holding peoplc in transit, because Congress may regulate the "channels of interstate commeree"); Katzcnbach v. McClung, 379 U.S. 294 (1964) (upholding enforcement of a federal law prohibiting discrimination in places of public accommodation against a local restaurant on the basis of the aggregation principle).

63. See Perez v. United States, 402 U.S. 146 (1971) (upholding a federal law criminalizing loansharking on the ground that accumulated instances of loan-sharking would affect interstate commeree).

64. 426 U.S. 833 (1976).

65. Id. at $835-36$.

66. Id. at 852 .

67. Id. at $847-48$,

68. 329 U.S. 183 (1968).

69. See National League, 426 U.S. at 854-55.

70. Id. at 851 .

71. 469 U.S. 528 (1985).

72. Id. at $545-46$.

73. See id. at 530-31.

74. Id. at 547-55. See also discussion of academic commentary infra Parts II.A-B. 
Garcia opinions both produced chiding dissents, one of which presaged the changes to come in the Court's approach to the commerce power. ${ }^{75}$

\section{United States v. Lopez}

After Justices Brennan and Marshall left the Court and were replaced by justices more sympathetic to states' rights, the Court's conservative majority was poised to find a test case to curtail the scope of the commerce power. The Gun-Free School Zones Act of 1990 (GFSZA), which made it illegal for "any individual knowingly to possess a firearm at a place that the individual knows, or has reasonable cause to believe, is a school zone, ${ }^{, 76}$ produced such a case. In United States $v$. Lopez, ${ }^{77}$ the Court struck down the GFSZA, limiting the use of the "substantial effects" standard articulated in Jones \& Laughlin. ${ }^{78}$ The Court presented a two-part test for determining whether an activity substantially affects interstate commerce. First, if the activity is at all associated with "commerce" or "economic enterprise," then the Court must assume that it substantially affects interstate commerce. ${ }^{79}$ If the regulated activity does not satisfy the first prong of this test, a statute still may survive commerce power scrutiny if it contains a jurisdictional element ensuring that no activities other than those affecting interstate commerce will be regulated. ${ }^{80}$ The Court also spoke to the role of legislative findings in the lawful use of the commerce power, holding that if the activity at issue obviously affects interstate commerce, there is no need for particularized findings, but that if such effects are not "visible to the naked eye," Congress must include findings to facilitate judicial evaluation of the legislative judgment. ${ }^{81}$

The Lopez Court offered some guidance on whether certain controversial cases remained good law. For example, the Court verified the

75. See National League, 426 U.S. at $856-80$ (Brennan, J., dissenting); Garcia, 469 U.S. at 580 (Rehnquist, J., dissenting) ("I do not think it incumbent on those of us in dissent to spell out further the fine points of a principle that will, I am confident, in time again command the support of a majority of this Court."). One commentator has characterized Justice Rehnquist's Garcia dissent as Iacking only "an actuarial table to indieate how soon the Court could expect to lose its older, liberal members." See Larry D. Kramer, Putting the Politics Back into the Political Safeguards of Federalism, I00 Colum. L. REv. 2I5, 2 I7 n.1I (2000).

76. I8 U.S.C. $\S 922(q)(I)(A)$ (Supp. V I988).

77. 514 U.S. 549 (I995).

78. NLRB v. Jones \& Laughlin Steel Corp., 301 U.S. 1 (1937). The Lopez Court left intact the authority of Congress to regulate the channels of interstate commerce. Lopez, 5 I4 U.S. at 558 (citing Heart of Atlanta Motel, Inc. v. United States, 379 U.S. 24I (1964); United States v. Darby, 312 U.S. I00 (1941); Caminetti v. United States, 242 U.S. 470 (19I7)). In addition, the Court did not disturb Congress's ability to regulate the instrumentalities of interstate commerce or objects or activities in interstate commerce, "even though the threat may come only from intrastate activities." Lopez, 514 U.S. at 558 (citing Perez v. United States, 402 U.S. 146 (1971); The Shreveport Rate Cases, 234 U.S. $342(1914))$.

79. Lopez, 5 I4 U.S. at 559-61.

80. Id. at $56 \mathrm{I}$.

8I. Id. at 563 . 
continuing validity of Wickard, because the economic character of the activity at issue in that case would satisfy the first prong of the substantial effects test. ${ }^{82}$ The Court also affirmed its holdings in Katzenbach $v$. McClung ${ }^{83}$ and Heart of Atlanta Motel, Inc., v. United States, ${ }^{84}$ in which it had upheld civil rights laws passed under the commercc power, because those cases involved commercial activity in a way that "the possession of a gun in a school zone does not." 85 The Court's focus on the distinction between the economic and noneconomic character of regulatcd activities, while in some ways similar to the manufacturing-commerce distinction, represented a new direction for the Court. The aim of the Lopez standard articulated by Chief Justice Rehnquist does not seem to be adhering to the semantics of the Progressive Era Court, but rather ending Congress's practice of "pil[ing] inference upon inference" to justify federal statutes to the detriment of state sovereignty. ${ }^{86}$

The contrasting views articulated in Lopez's two concurring opinions provide some sense of the different beliefs about judicial review of federalism within the five-justice majority. Justice Thomas concluded that the substantial effects test had no basis in the meaning of the word "commerce" at the Founding or in the Commerce Clause read in pari materia with the rest of Article $\mathrm{I}^{87} \mathrm{He}$ decried the use of the Necessary and Proper Clause to support the substantial effects test ${ }^{88}$ and advocated a return to the commerce-manufacturing distinction. ${ }^{89}$ In contrast, Justice Kennedy's concurring opinion, joined by Justice O'Connor, reads as a critique of the political safeguards thesis. ${ }^{90}$ Justice Kennedy argues that there is a role for judicial review of the Commerce Clause, although he counsels restraint in enforcing the outer boundaries of the commerce power. ${ }^{91}$

82. Id. at 560. But see id. ("Wickard is ... perhaps the most far reaching example of Commerce Clause authority over intrastate activity.").

83. 379 U.S. 294 (1964).

84. 379 U.S. 241 (1964).

85. Lopez, 514 U.S. at 560. See also supra note 62.

86. Lopez, 514 U.S. at 567.

87. Id. at 585 (Thomas, J., concurring).

88. Id. at $588-89$.

89. Id. at 586-87.

90. None of the opinions in Lopez explicitly addresses the political safeguards thesis. For an examination of this curious omission, see John C. Yoo, The Judicial Safeguards of Federalism, $70 \mathrm{~S}$. CAL. L. Rev. 1311, 1349-53 (1997) (arguing that aftcr the Court's recent fedcralism decisions, Garcia is no longer good law).

91. Lopez, 514 U.S. at 568-83 (Kennedy, J., concurring). Justice Kennedy's introduction to his concurrence illustrates this theme:

The history of the judicial struggle to interpret the Commerce Clause during the transition from the economic system the Founders knew to the single, national market still emergent in our own era counsels great restraint before thc Court determines that the Clause is insufficient to support an exercise of the national powcr. That history gives me somc pause about today's decision, but 1 join the Court's opinion with these observations on what 1 conceive to be its necessary though limited holding. 
Justice Kennedy also celebrates federalism as the most innovative elcment of the Constitution because it capitalizes on the counterintuitive insight that dual sovereignty increases liberty. ${ }^{92}$ The opinion also critiques the contentbased categories, such as the earlier distinction between manufacturing and commerce, as amorphous and unworkable. ${ }^{93}$

Lopez also produced three dissents. Justice Stevens wrote a succinct opinion endorsing a functional, pragmatic approach to Commerce Clause jurisprudence ${ }^{94}$ and calling the majority opinion "radical." in a lengthier dissent, critiques both the majority's return to a categorical approach to the commerce power and its departure from a rational basis test for evaluating federal legislation. ${ }^{96}$ The opinion cautions against a return to the Progressive Era tendency to substitute the Court's judgment for that of Congress. ${ }^{97}$ Justice Souter reasons that the hesitancy to substitute judicial preferences for legislative preferences supports continuing the broad deference to Congress with regard to the scope of the commerce power. ${ }^{98}$ Finally, Justice Breyer's dissent, in addition to attacking the porosity of the economic-noneconomic distinction used by the majority, ${ }^{99}$ provides evidentiary support for the rational basis test advocated by Justices Stevens and Souter by marshaling a bevy of academic and anecdotal support for the finding that guns in schools affect commerce at the interstate level. ${ }^{100}$

\section{United States v. Morrison}

The Court affirmed the Lopez standard in United States v. Morrison, in which the Court struck down the Violence Against Women Act (VAWA). ${ }^{101}$ VAWA provided a federal tort remedy for victims of gendermotivated violence. ${ }^{102}$ The case centered on whether the Commerce Clause

92. Id. at 575-78.

93. Id. at 574. Curiously, Justice Kennedy elided the potential problems with Chief Justice Rehnquist's economic-noneconomic distinction.

94. Justiee Stevens wrote:

In my judgment, Congress' power to regulate commerce in firearms includes the power to prohibit possession of guns at any location because of their potentially harmful use; it necessarily follows that Congress may also prohibit their possession in particular markets. The market for the possession of handguns by school-age children is, distressingly, substantial. Whether or not the national interest in eliminating that market would have justified federal legislation in 1789 , it surely does today.

Id. at 602-03 (Stevens, J., dissenting) (citation omitted).

95. Id. at 602 .

96. Lopez, 514 U.S. at 603 (Souter, J., dissenting)

97. Id. at 605-07.

98. Id.

99. Id. at 628-29 (Breyer, J., dissenting).

100. Id. at $618-23$. Justice Breyer included a lengthy appendix to substantiate this finding. Id. at

102. Id. at 601-02. 
(or, alternatively, section 5 of the Fourteenth Amendment) gave Congress the power to enact VAWA. ${ }^{103}$ With respect to the commerce power, the Court found that VAWA failed to satisfy any of the elements of the Lopez standard. ${ }^{104}$ The Court quickly concluded that gender-motivated violence was not an economic activity ${ }^{105}$ and that the statute clearly did not contain a satisfactory jurisdictional element. ${ }^{106}$ Determining whether VAWA had a substantial effect on interstate commerce required slightly more analysis, but the Court ultimately decided that deference to congressional findings of an aggregate effect of gender-motivated violence on interstate commerce would "completely obliterate the Constitution's distinction between national and local authority." 107 In making this determination, the Court clarified some of its rationale for its decisions in Lopez and Morrison: "[W]e can think of no better example of the police power, which the Founders denied the National Government and reposed in the States, than the suppression of violent crime and vindication of its victims." 108 What is unclear from this statement is the proper approach when exercise of the police power, and other powers traditionally associated with local control, discernibly affects the welfare of citizens in other states. The remainder of this Comment addresses this question.

\section{II}

\section{The Scope of the Commerce Clause: Identifying the Flaws of the Political SafEguards and NarRow Scope APPROACHES}

Two academic theories generally explain the Court's shifting Commerce Clause jurisprudence. Proponents of the political safeguards of federalism approach, associated with Herbert Wechsler and Jesse Choper, generally favor little or no judicial review of the balance of power between

103. Id. at 607.

104. Id. at 613-17.

105. Id. at 613 .

106. Id. For commentary on the possibility of using the jurisdictional element to dilute Lopez, see Diane McGimsey, Comment, The Commerce Clause and Federalism after Lopez and Morrison: The Case for Closing the Jurisdictional-Element Loophole, 90 CALIF. L. REv. 1675 (2002).

107. Morrison, 529 U.S. at 615.

108. Id. at 618. In Morrison, the Court also ruled that section 5 of the Fourteenth Amendment did not provide Congress with the power to enact VAWA. Id. at 615. Although the Fourteenth Amendment is beyond the scope of this Comment, the relationship between remedial civil rights legislation and federalism requires a few words of clarification. The Court previously has recognized the authority of Congress to enact civil rights legislation under the Commerce Clause. Heart of Atlanta Motel, Inc. v. United States, 379 U.S. 241 (1964); Katzenbach v. McClung, 379 U.S. 294 (1964). Although the Lopez Court affirmed these holdings, some commentators fear that Morrison portends more severe limitations of the power to enact remedial legislation under both the Commerce Clause and section 5. See, e.g., Robert C. Post \& Reva B. Siegel, Equal Protection by Law: Federal Antidiscrimination Legislation After Morrison and Kimel, 110 YALE L.J. 441 (2000) (analyzing the limitations the Court's recent section 5 decisions place on antidiscrimination law). Political market failure arguments may apply to remedial legislation, but such arguments are properly seen as an extension of this Comment rather than the focus of it. 
Congress and the states. ${ }^{109}$ Advocates of this approach argue that states can represent their interests adequately at the federal level and that judicial nullification of federal legislation amounts to inappropriate meddling by a countermajoritarian institution. ${ }^{110}$ In contrast, another group of historically and textually oriented scholars advocates a narrow scope approach, arguing that the political safeguards theory violates the Constitution's structural commitment to federalism. ${ }^{111}$ Although both approaehes have merit, both also have significant flaws. The political safeguards approach grants Congress near plenary power to legislate and ignores the clear constitutional commitment to a limited set of congressional powers. The narrow scope approach interprets "commerce" in an overly atomistic way, leading to an ultimately unworkable doctrine. ${ }^{112}$ This Part describes each theory and then discusses their shortcomings.

\section{A. The Political Safeguards Approach to the Commerce Clause: Allowing Congress Broad Powers}

The political safeguards theory, which rose to prominence in the middle of the twentieth century, supports an expansive view of commerce and would grant Congress near plenary power under the Commerce Clause. ${ }^{113}$ This line of commentary provided theoretical support for the dramatic shifts in Commerce Clause jurisprudence initiated by the New Deal Court. The primary theoretical justification for the holdings typified by Jones \& Laughli ${ }^{114}$ and Wickard v. Filburn ${ }^{115}$ was that the states' interests are sufficiently represented in Congress, obviating the need for judicial policing of the balance between federal and state power. ${ }^{116}$

Herbert Wechsler was the first scholar to articulate this theory in a brief, though widely cited, ${ }^{17}$ article titled The Political Safeguards of Federalism. ${ }^{118}$ Wechsler argues that the national political process would

109. See CHOPER, supra note 6; Wechsler, supra note 5.

110. See CHOPER, supra note 6; Wechslcr, supra note 5.

111. See Saikrishna B. Prakash \& John C. Yoo, The Puzzling Persistence of Process-Based Federalism Theories, 79 TEx. L. REv. 1459, 1472 (2001).

112. Examples of these doctrinal problems include the pre-New Deal Court's distinction between manufacturing and commerce and the Court's adoption in Lopez of a distinction between economic and noneconomic activity. The problem with these distinctions is that they are largely semantic and are not based on a theory of the purpose of the Commerce Clause. This lack of theoretical justification for the distinctions provides courts with little guidance when deciding cases involving activities that fall on the borders of the semantic distinctions.

113. See CHOPER, supra note 6; Wechsler, supra note 5.

114. NLRB v. Jones \& Laughlin Steel Corp., 301 U.S. 1 (1937).

115. 317 U.S. 111 (1942).

116. See Wechsler, supra note 5.

117. One citation count ranked the article as the sixty-ninth most-cited law review article since 1956. See Fred R. Shapiro, The Most-Cited Law Review Articles Revisited, 71 CHI.-KENT L. REv. 751, 770 tbl. 1 (1996).

118. Wechsler, supra note 5. At least one seholar has argucd that Wechsler's approach is based, in part, on the famous footnote 4 of United States v. Carolene Products Co., 304 U.S. 144, 152 n.4 
protect the states from an overbearing federal government. He believes that the equal representation of the states in the Senate plays a particularly important role in allowing states to assert their interests at the national level. ${ }^{119}$ Wechsler also argues that the electoral college, which forces presidential candidates to campaign state by state, buttresses the states' ability to have their interests represented at the national level. ${ }^{120}$ The role played by the states in affecting the composition of the federal government, Wechsler argues, is "well-adapted to retarding or restraining new intrusions by the center on the domain of the states." 121 Wechsler maintains that, because the states have sufficient representation at the federal level, the Court is on "weakest ground" when it uses the Commerce Clause to strike down an act of Congress. ${ }^{122}$

Jesse Choper made the next major developments in the political safeguards thesis. Choper not only endorses Wechsler's arguments but also expands the theory's scope by using it to justify the institutional purposes of the Supreme Court. Choper mainly argues that issues regarding the scope of congressional power with respect to the states should be nonjusticiable. ${ }^{123}$ This "Federalism Proposal" is part of Choper's larger theory that the Court's proper role is to protect individual rights. ${ }^{124}$ Because individuals are the most susceptible to being overrun by majorities, Choper argues, all matters of individual rights should be justiciable. ${ }^{125}$ But where there is a political process to determine the allocation of power, either between the states and the federal government or between branches of the federal government, the Court should not intervene. ${ }^{126}$

Choper's theory is, in some ways, an outgrowth of Alexander Bickel's argument that the Court is the least democratic branch of the federal government. ${ }^{127}$ Choper argues that the Court has limited institutional capital and should reserve this capital to protect the rights of individuals who have little recourse to the democratic process. ${ }^{128}$

(1938). See Yoo, supra note 90, at 1314. In footnote 4, Justice Stone reasoned that the Court should preserve its political capital for protecting the interests of "discrete and insular" minorities. Carolene Products, 304 U.S. at 152 n.4. Yoo explained that "by withdrawing from contentious federalism questions, it was hoped, the judiciary would save its political capital for use in defending individual and minority rights." Yoo, supra note 90 , at 1314 .

119. Wechsler, supra note 5, at 547-48. Wechsler authored this article before the rise of intensely empirical political science, so most of his arguments are eonjeetural and his evidence limited.

120. Id. at 557-58.

121. Id. at 558 .

122. Id. at 559.

123. CHOPER, supra note 6 , at 175.

124. Id. at 193-205.

125. Id. at 70-79.

126. Id. at 263 .

127. See generally Alexander M. Bickel, The Least Dangerous Branch: The Supreme Court at the Bar of Politics (1962).

128. CHOPER, supra note 6, at 169. 
As discussed below, scholars have critiqued this theory on multiple levels. Some argue that the empirical political science evidence on which Choper relies is faulty and antiquated. ${ }^{129}$ Another argument against Choper's functionalist approach is that it has no basis in the text of the Constitution. ${ }^{130} \mathrm{~A}$ related critique is that Choper's theory of nonjusticiability eviscerates the structural constitutional goal of limiting the power of Congress. ${ }^{131}$ These last two lines of attack relate to the second major strain of Commerce Clause scholarship, the narrow scope theory, which takes a more historically based approach to the Commerce Clause.

\section{B. The Narrow Scope Approach to the Commerce Clause: Limiting the Reach of Congress}

The second strain of Commerce Clause scholarship focuses on the meaning of "commerce" at the Framing. The originalist scholars taking this approach argue that, at the Framing, "commerce" had a narrow, circumscribed meaning, and that the Court should apply this narrower meaning in deciding Commerce Clause cases. Recent proponents of this view, which originated with Albert Abel, ${ }^{132}$ include Richard Epstein, Raoul Berger, and Randy Barnett. ${ }^{133}$

In his 1987 article The Proper Scope of the Commerce Power, Epstein resurrects Abel's argument and posits that both the early understanding of commerce and the structure of limited powers in Article I support a narrow definition of "commerce" that excludes manufacturing. ${ }^{134}$ This argument, like Justice Thomas's concurrence in Lopez, ${ }^{135}$ advocates a return to the doctrinal standard of E.C. Knight, ${ }^{136}$ which prevented Congress from regulating the manufacture of goods. Epstein decries the New Deal Court's use of the substantial effects test to eliminate any jurisdictional limit previously imposed by the Commerce Clause. ${ }^{137}$ He notes the detrimental effect that the expansion of the commerce power has on the options of exit and voice

129. For academic criticism in this vein, see Carol F. Lee, The Political Safeguards of Federalism? Congressional Responses to Supreme Court Decisions on State and Local Liability, 20 URB. LAW. 301, 307 (1988) (arguing that Congress is not very protective of important state interests). Justice Powell also critiqued Wechsler's empirical claim in a dissent in Garcia v. San Antonio Metropolitan Transit Authority. See 469 U.S. 528, 564-67 (1985) (Powell, J., dissenting).

130. See Prakash \& Yoo, supra note 111, at 1464-65.

131. See, e.g., id. at 1472 ("Reading the Constitution in the manner proposed by politicalsafeguards theorists does violencc to the basic structure of the Constitution's grant of powers to the national government.").

132. Albert S. Abel, The Commerce Clause in the Constitutional Convention and in Contemporary Comment, 25 MiNN. L. REv. 432 (1941) (arguing for a constrained view of the commerce power based on the meaning of the term "commerce" at the Framing).

133. See Barnett, supra note 11; Berger, supra note 11; Epstein, supra note 11.

134. See Epstein, supra note 11, at 1393-98.

135. United States v. Lopez, 514 U.S. 549, 584 (1985) (Thomas, J., concurring).

136. United States v. E.C. Knight Co., 156 U.S. 1 (1895).

137. Id. at $1443-54$. 
at the state level. ${ }^{138}$ Although Epstein views Lopez as a step in the right direction, he finds that the Chief Justice's opinion did not go far enough-in Epstein's opinion, "a prompt return to the pre-1937 view of the Commerce Clause" is needed. ${ }^{139}$ Epstein makes some historical arguments about the original meaning of "commerce" and "regulate," but he also proffers structural arguments.

Other narrow scope scholars tend to make more use of history than Epstein does. For example, Randy Barnett uses a variety of historical materials, such as contemporary dictionaries, ${ }^{140}$ the Federalist Papers, ${ }^{141}$ and the proceedings of the Ratification Convention ${ }^{142}$ to support his argument that at the Framing, "commerce" meant "trade" or "exchange" and did not include manufacturing. ${ }^{143}$ Barnett's work responds to that of other legal historians who have argued that the historical meaning of "commerce" is broader than merely "trade" or "exchange."144 For the purposes of this Comment, however, the important normative move made by narrow scope theorists has been to argue that the original meaning of "commerce" should determine the scope of fcderal jurisdiction.

\section{Weaknesses of the Two Traditional Approaches to Commerce Clause Scholarship}

\section{Political Safeguards}

Neither strain of Commerce Clause scholarship provides a basis for a workable doctrine that preserves the values underlying federalism while staying true to the still-relevant justifications for centralized power that gave rise to the Commerce Clause in the first place. ${ }^{145}$ The political

138. Id. at 1454. This critique is rooted in the seminal public choice work by Albert Hirschman. See Albert O. Hirschman, Exit, Voice, and Loyalty: Responses to Decline in Firms, ORganizations, and STATES (1970) (exploring the different possible responses of citizens and consumers to dissatisfaction). See also discussion of public choice infra Part lll.

139. See Richard A. Epstein, Constitutional Faith and the Commerce Clause, 71 Notre Dame L. REv. 167, 169 (1996).

140. See Barnett, supra note 11, at 113-14.

141. Id. at 115-16.

142. Id. at $116-25$.

143. Id. at 125 .

144. See, e.g., Nelson \& Pushaw, supra note 13, at 9-10 (arguing that at the Framing, the term "commerce" referred to the manufacture as well as the movement of goods).

145. Choper anticipated this criticism. Responding to the critique that his theory failed to respect the Framers' intent to provide a limited set of powers to Congress and to reserve wide areas of regulation to the states (as reflected in the Federalist Papers), he argues that the Federalist Papers were equivocal on the proper role of judicial review. See CHOPER, supra note 6, at 242. According to Choper, the Federalist Papers are not appropriate guides to the intent and meaning of the Constitution. Id. Given this historical uncertainty, Choper argues that the functional history of the interaction between the political branches and the Supreme Court supported his claim that the boundary between congressional and state power should be nonjusticiable. Id. To back this claim, Choper marshals a wide array of evidence from political scientists to demonstrate that states are able to represent their interests adequately at the federal level. Id. at 276-304. 
safeguards thesis, insofar as it advocates the nonjusticiability of the balance of federal and state power under the Commerce Clause, eviscerates the value of federalism by leaving the states to fend for themselves in Congress. A problem perennially ignored by political safeguards scholars is the structural difference between a uniform federal rule to which all citizens must adhere and the more nuanced treatment and experimentation with policy associated with having each state promulgate or not promulgate a law according to the desires of the citizens of that state. Political pluralism of this type has at least two related advantages over the uniformity of centralized law. First, having a variety of different rules to deal with a given regulatory problem does more to satisfy the policy preferences of individual citizens. Second, this variety of legal regimes means that citizens have the option of "exit." 46 If a given person prefers the legal approaches taken by another state, that person has the option of exiting the current state and moving to the other state. A uniform federal law governing all citizens on a given activity curtails this legal pluralism and undermines the option of exit. By passing a uniform law, Congress kills the chance of varied and independent legal cultures and institutions providing different solutions to a regulatory problem. ${ }^{147}$

These consequences of centralization can be severe, and political safeguards theorists who would forsake judicial review of the constitutionality of legislation passed under the Commerce Clause give short shrift to such problems. Absent the costly option of exit, ${ }^{148}$ one of the few avenues left to a citizen disgruntled with a uniform federal law is to voice her views to her congressperson or senator. Given the large number of people in any given congressional district, the voice of one person is unlikely to have any tangible effect on the law governing the actions of that citizen.

\section{Narrow Scope}

The narrow scope thesis also fails to offer any theoretical basis for permitting or prohibiting centralized power. The narrow scope theory faces two problems. First, the original definition of the words "commerce" and "regulate" will always be, at least to some degree, elusive. The resurgence of textualist jurisprudence, aided in part by the elevation of Justice Scalia to the Court, has provoked a vast literature on the merits of textual and

146. Hirschman pioneered this line of argument. See HIRSCHMAN, supra note 138.

147. Cf. Robert M. Cover, The Supreme Court, 1982 Term-Foreword: Nomos and Narrative, 97 HARV. L. Rev. 4 (1983) (discussing the ability of judges to kill legal pluralism by choosing one rule from among many possibilities).

148. Exit is, of course, still an option under a uniform federal law. A citizen could choose to exit the country entirely. One assumes, however, that this option is substantially more costly than an interstate move. 
historical approaches to adjudication. ${ }^{149}$ Although this debate is beyond the scope of this Comment, it testifies to the lurking indeterminacy of these approaches.

Second, and more important, those who advocate a return to a putative original definition of "commerce" that distinguishes between manufacturing and commerce ignore both the doctrinal difficulties associated with this distinction and the important functional lessons learned over two centuries of Commerce Clause jurisprudence. The problem with the manufacturingcommerce distinction is that commerce is a sprawling concept encapsulating a very wide range of activity in the modern economy. The great amount of activity that one could conceivably characterize as commerce makes line-drawing problems inevitable. Moreover, the functionalist viewpoint taught by cases such as Jones \& Laughlin ${ }^{150}$ supports the conclusion that a departure from the original understanding is particularly appropriate in the context of the Commerce Clause. ${ }^{151}$ At the Framing, the economy could hardly be considered national; most markets were local and agrarian. In the more than two centuries since that time, the national market has developed into part of a globalized, highly commoditized economy. It is not surprising, then, that the original text used to solve the problem of counterproductive state regulatory action or inaction in the context of largely local, agrarian markets may not function well when used to solve the same problem in the context of today's highly complex economy. Nevertheless, some of the difficulties identified by the Framers with respect to problematic state action and inaction remain. These difficulties require some framework for resolution. ${ }^{152}$

149. See antonin Scalia, A Matter of Interpretation: Federal Courts and the Law 45 (1997) (arguing that "the difficulties and uncertainties of determining original meaning and applying it to modem circumstances are negligible compared with the difficulties and uncertainties of the philosophy which says that the Constitution changes" (emphasis in original)). Pieces critical of the textualist approach include William N. Eskridge, Jr., The New Textualism, 37 UCLA L. Rev. 621 (1990); Bradley C. Karkkainen, "Plain Meaning": Justice Scalia's Jurisprudence of Strict Statutory Construction, 17 Harv. J.L. \& Pub. Pol'y 401 (1994); Richard J. Picrce, Jr., The Supreme Court's New Hypertextualism: An Invitation to Cacophony and Incoherence in the Administrative State, 95 Colum. L. Rev. 749, 750 (1995); William D. Popkin, An "Internal" Critique of Justice Scalia's Theory of Statutory Interpretation, 76 MINN. L. Rev. 1133 (1992); Nicholas S. Zeppos, Justice Scalia's Textualism: The "New" New Legal Process, 12 Cardozo L. Rev. 1597 (1991).

150. NLRB v. Jones \& Laughlin Steel Corp., 301 U.S. 1 (1937).

151. This is a valuable lesson of the political safeguards thesis. Choper argues that the Court must take a functionalist approach in order to preserve its institutional capital. If the Court is unresponsive to political and empirical realities, he contends, it risks noncompliance with its holdings. See CHOPER, supra note 6, at 67-70.

152. It is worth noting that while this Comment is skeptical about the use of historical and textual approaches to Commerce Clause jurisprudence, it endorses reliance on the original purpose of the Commerce Clause. Inhibiting collective action problcms remains relevant because states remain selfinterested entities. 


\section{III}

\section{Public Choice Theory, Political Market Failure, AND THE COMMERCE POWER}

While the political safeguards approach and the narrow scope approach both enjoy support among academics, neither provides much aid in analyzing post-Lopez Commerce Clause jurisprudence. The political safeguards approach advocates no judicial review of Commerce Clause cases, so it cannot aid in fine-tuning the Lopez standard. The narrow scope thesis, having a largely historical basis, does not employ the tools of policy analysis that can resolve questions left open by the Lopez standards. A better approach would embrace the insights of public choice theory and, more specifically, political market failure theory. Under this approach, where a political market failure exists or might plausibly exist, there is a policy rationale for permitting congressional regulation. Where there is little or no likelihood of political market failure, congressional regulation is less justified. This framework has the benefit of preserving the structural federalist principles of the Constitution while addressing the economic balkanization concerns that helped to justify the Commerce Clause in the first place.

After providing an outline of public choice theory and political market failure, this Part identifies three rationales for applying the political market failure framework to the Commerce Clause dilemma. First, the wideranging public choice literature in the spirit of Charles Tiebout ${ }^{153}$ identifies externalities and holdouts as conditions that can produce political market failure and suboptimal regulation in situations involving self-interested state political actors and weak centralized power. ${ }^{154}$ Second, Dormant Commerce Clause doctrine, a cognate of Commerce Clause doctrine, adopts a skeptical model of state political actors consistent with a theory of political market failure. ${ }^{155}$ An analogous theory of the federal commerce power justifying congressional action as necessary to stem the losses from political market failure is solid and defensible, as well as doctrinally clearer than the economic-noneconomic distinction asserted in Lopez. ${ }^{156}$ Finally, the arguments of the Framers, laid out in the earlier discussion of their original purpose, justify the Commerce Clause as a solution to the collective action problem posed by too little centralized power to stop the regulatory warfare carried out by the self-interested states. ${ }^{157}$

153. See Charles M. Tiebout, A Pure Theory of Local Expenditures, 64 J. PoL. Econ. 416 (1956).

154. See infra Parts III.A-B.

155. See infra Part III.C.

156. United States v. Lopez, 5 I4 U.S. 549 (1995).

157. See supra Part 1.A. See also infra Part Ill.D. 


\section{A. Introduction to Public Choice Theory and Political Market Failure}

Public choice theory, broadly speaking, is the analysis of how political institutions and markets affect the satisfaction of citizens' political preferences. ${ }^{158}$ The theory explains how to decide whether to allocate certain powers to a centralized government (in the case of the United States, the federal government) or to a decentralized government (the states). In general, public choice theorists approve of political decentralization because it allows political pluralism among jurisdictions and permits citizens to migrate to jurisdictions that suit their political preferences. ${ }^{59}$ However, where these pluralistic political markets fail to provide for citizens' political preferences, public choice theory recognizes that power must be allocated to a centralized government. Externalities and holdouts represent two types of political market failures making such centralized authority necessary. In the absence of federal power to regulate the activities that cause such market failures, states may engage in detrimental regulatory warfare, leading to economic balkanization and economic injury to all citizens.

\section{B. Political Market Failure: The Public Choice Argument for Occasional Centralization}

The economics of centralization and decentralization recognized by public choice theory relate directly to the original purposes and goals of the Commerce Clause. ${ }^{160}$ The modern public choice analysis of jurisdictional competition and centralized power originated with Charles Tiebout, a stalwart in the public finance field. ${ }^{161}$ In the I950s, public finance theorists were vexed by the difficulty of finding a method for determining the preferences of multiple individuals. ${ }^{162}$ Tiebout's innovation was to argue that ceding power to local governments could solve the problems of preference aggregation because local governments can vary their policies in a way that a unitary national government cannot. ${ }^{163}$

158. Robert D. Cooter, The Strategic Constitution 7 (2000).

159. Id. at 129. Political pluralism and migration are favorable because they facilitate the ultimate goal of preference satisfaction.

160. See infra Part 1.A.

161. See Tiebout, supra note 153.

162. Two prominent theorists had argued that this problem of preference aggregation at the federal level was intractable. Tiebout's theory responded to these theorists' work. See id. (citing Richard A. Musgrave, The Voluntary Exchange Theory of Public Economy, 52 Q.J. Econ. 213-17 (1939) (arguing that aggregating political preferences for federal expenditures is an extremely complex problem that may be insoluble); Paul A. Samuelson, The Pure Theory of Public Expenditure, 36 Rev. Econ. \& STAT. $387-89$ (1954) (showing that the preference aggregation problem is even more difficult than Musgrave demonstratcd)).

163. See Tiebout, supra note 153. 
This theory, however, depended on the existence of four unrealistic conditions: costless mobility of citizens, ${ }^{164}$ complete information about all policies in every jurisdiction, the complete absence of externalities, and a large number of jurisdictions from which a citizen may choose. ${ }^{165}$ Under these conditions, Tiebout hypothesized, the market for local government would be perfect in the sense that the allocation of citizens based on their policy preferences would be optimal. Every citizen would be living in a jurisdiction that exactly suited that citizen's policy preferences. Aware that this assumption of frictionless markets for the provision of public goods by local governments was unrealistic, Tiebout nevertheless proffered his theoretical insights as a tool to make recommendations regarding the proper limits on federal power. ${ }^{166} \mathrm{He}$ advocated policies that would ease residential mobility and increase information about other communities, arguing that these measures would increase societal well-being as people moved to the areas that best suited them. ${ }^{167}$ It is difficult to overstate the importance of Tiebout's insight, which is now a primary argument for the strengths of decentralized government. ${ }^{168}$

\section{Externalities}

Later work on the economics of public choice used the problems with Tiebout's assumptions to justify centralization. ${ }^{169}$ The public choice analysis of externalities is perhaps the clearest application of this insight. Externalities are present whenever the consumption behavior of one person affects the well-being of another. ${ }^{170}$ Positive externalities affect others in a beneficial way, while negative externalities decrease the well-being of

164. Constrained mobility has a number of implications for federalism policy. Perhaps the most important problem posed by costly mobility is its effect on the optimal number of jurisdictions. This optimal number will depend on a number of factors. If the immobile citizens are grouped so that those with similar policy preferences reside within a reasonable degree of proximity to one another, there is an argument for having a multiplicity of jurisdictions. Multiple jurisdictions allow gains resulting from supplying different levels of public goods for groups that have different preferences with respect to those public goods. However, if citizens have what amounts to a random distribution of preferences, and mobility is extremely costly, the argument for a multiplicity of jurisdictions is much weaker. If preferences are randomly distributed and citizens cannot move to their preferred jurisdictions, having a multiplicity of jurisdictions adds to the transaction costs of legislating while providing little, if any, gains in preference satisfaction. In such a situation, a single, uniform government is optimal.

165. Tiebout, supra note 153 , at 419.

166. Id. at 423-24.

167. Id.

168. See, e.g., Steven G. Calabresi, Federalism and the Rehnquist Court: A Normative Defense, 574 Annals Am. Acad. Pol. \& Soc. Scl. 24, 27 (2001).

169. For a thorough review of the Tiebout hypothesis and later developments of this theory, see Robert P. Inman \& Daniel L. Rubinfeld, Making Sense of the Antitrust State-Action Doctrine: Balancing Political Participation and Economic Efficiency in Regulatory Federalism, 75 TEX. L. REv. 1203, $1217-49$ (1997).

170. See COOTER, supra note 158 , at 108-09. 
others. ${ }^{171}$ Externalities in the interjurisdictional context are often called spillovers. ${ }^{172}$ Pollution is one of the most common examples of a negative spillover. If one jurisdiction produces a substantial amount of pollution that is borne by a different jurisdiction, people may flock to the pollutionproducing jurisdiction, because this jurisdiction receives all the benefits of the activity without having to bear all of the costs. This situation reduces the incentive for the pollution-producing jurisdiction to enact policies aimed at reducing pollution.

At the same time, the government of the jurisdiction experiencing the pollution will be able to do little to alleviate the pollution by itself. Consequently, citizens of that state may migrate to a different jurisdiction to avoid the pollution their home jurisdiction is unable to regulate. This disconnect between the people experiencing the pollution's negative effects and the people able to regulate the pollution can produce larger amounts of pollution than would occur in the absence of an externality, leading to what is known as a "race to the bottom." 173 States that export a significant amount of pollution may relax environmental standards to encourage entry by citizens and capital. If other states do likewise, significant degradation of environmental standards may result. This process is a type of political market failure because the preferences of the citizens experiencing the pollution are not reflected in the policies of the pollution-producing jurisdiction. ${ }^{174}$

One solution to the race-to-the-bottom problem is to allocate to a centralized government the power to regulate activities creating interjurisdictional pollution. A centralized government will experience both the benefits of whatever activity produces the pollution and the costs of the pollution produced by that activity. Because it bears both costs and benefits, and any increase in pollution would occur in the jurisdiction covered by the centralized government, the centralized government has little to gain

171. Id.

172. Id. at $127-28$.

173. Daniel Fischel cites William Cary as the originator of the phrase "race for the bottom." See Daniel R. Fischel, The "Race to the Bottom" Revisited: Reflections on Recent Developments in Delaware's Corporation Law, 76 Nw. U. L. Rev. 913, 913 n.4 (1982) (citing William Cary, Federalism and Corporate Law: Reflections Upon Delaware, 83 YALE L.J. 663, 666 (1974)).

174. The Coase Theorem tcaches that in the abscnce of transaction costs, everyone could bargain with everyone else to reach efficiency. See Ronald Coase, The Problem of Social Cost, 3 J.L. \& EcoN. 1 (1960) (providing original statcment of Coase Theorem); CooTER, supra note 158, at 108. For example, the citizens of the pollution-producing state could offer a payment to the industries that cause the pollution to induce them to reduce production. Or, more rcalistically, the governments of the two states could enter into some type of regulatory compact to deal with the problem of pollution. However, a number of features of this bargaining problem dramatically increase the transaction costs of coming to an agreement. First, politieal bargaining is an expensive process that requires the time and expense of state actors. Second, if there are more than two actors, the problem of holdouts may be acute. See infra Part 11l.B.2. Third, citizens may feel entitled to a pollution-free environment and may bc unwilling to pay for a reduction in pollution caused by a neighboring state. 
by relaxing environmental standards. This rationale provides a strong argument for granting the federal government expansive power to regulate activities that might create negative spillovers and, by implication, races to the bottom.

Unfortunately, whenever the justices of the Court address the race-tothe-bottom argument, they do so either disapprovingly ${ }^{175}$ or in dissent. ${ }^{176}$ There is also significant academic debate about the role of potential races to the bottom in federalism questions. Some public choice scholars argue that a race to the bottom presents a strong argument for centralized government jurisdiction over the relevant activity. For example, Robert Cooter argues that whenever spillovers exist, the ideal government for regulating the activity causing the spillover is the smallest government that encompasses all the costs and benefits of the activity. ${ }^{177}$ Sometimes it is feasible to create special districts to deal with the activities that produce spillovers. ${ }^{178} \mathrm{~A}$ special district may not be politically possible, however, when one jurisdiction's negative spillovers affect a neighboring jurisdiction; the spillover-producing jurisdiction has little incentive to enter into an agreement that would require it to curtail the activity. When special districts are not possible, as will often be the case in interstate disputes over spillovers, there is good reason to give the federal government authority to regulate the relevant activity. ${ }^{179}$

At least one scholar, however, has cautioned against invoking the race-to-the-bottom rationale too indiscriminately. Richard Revesz argues that many academics and policymakers too casually invoke the race-to-thebottom argument to justify centralized regulation of the environment. ${ }^{180}$ According to Revesz, courts should permit federal regulation only when there are clear reasons for believing that state regulation will not

175. See Saenz v. Roe, 526 U.S. 489, 509-10 (1999). Justice Stevens wrote for the majority: The Solicitor General also suggests that we should recognize the congressional concern addressed in the legislative history ... that the "States might engage in a 'raee to the bottom' in setting the benefit Icvels in their [benefit] programs." Again, it is difficult to see why that concern should be any greater under [the benefit program at issue than under earlier programs]. The evidence reviewed by the Distriet Court indicates that the savings resulting from the discriminatory policy, if spread equitably throughout the entire program, would have only a miniscule [sic] impact on benefit levels. Indeed, as one of the legislators apparently interpreted this concern, it would logically prompt the States to reduce benefit levels sufficiently "to encourage emigration of benefit recipients." But speeulation about sueh an Id. unlikely eventuality provides no basis for upholding [the law in question].

176. See Solid Waste Agency v. United States Army Corps of Eng'rs, 531 U.S. 159, 195-96 (2001) (Stevens, J., dissenting); Coll. Sav. Bank v. Fla. Prepaid Postsecondary Educ. Expense Bd., 527 U.S. 666, 703 (1999) (Breyer, J., dissenting).

177. COOTER, supra note 158 , at 107.

178. Id. at 106-07.

179. Id.

180. See Richard L. Revesz, Rehabilitating Interstate Competition: Rethinking the "Race-to-theBottom" Rationale for Federal Environmental Regulation, 67 N.Y.U. L. REv. 1210 (1992). 
adequately control pollution. ${ }^{181}$ Revesz's insight-that the race-to-thebottom argument should be thought through to ensure that centralized government is the proper solution to the relevant problem-is valuable. ${ }^{182}$ The textual and historical commitments to federalism, as well as the sound policy reasons for decentralized government, suggest that the use of centralized power must be justified. Races to the bottom created by negative externalities provide such a justification, but only in situations where there is a colorable concern that such a race will take place. ${ }^{183}$ For this reason, this Comment advocates an expansive approach to the Commerce Clause when a court perceives substantial indications that a negative externality or a holdout problem is producing or will probably produce a race to the bottom.

\section{Holdouts}

Holdouts are another market failure that permit a jurisdiction to externalize harm. ${ }^{184}$ The primary difference between holdouts and externalities is the incentive structure that gives rise to each mechanism. The incentive to create externalities exists independent of the regulatory actions of neighboring states. If a state has the ability to inflict harm on a neighboring jurisdiction and avoid harm to itself through an activity that produces negative externalities, self-interest will provide an incentive to permit this activity. In contrast, the incentives for holdouts arise from the interaction of multiple jurisdictions. Holdouts are a potential problem whenever unanimity is needed for a decision. When each actor in a group needs to consent to

181. Id. at 1252-53. An important part of Revesz's argument is the distinction between races to the bottom and negative externalities. Id. at 1221-24. He makes a somewhat convincing case that arguments for centralized regulation based solely on a potential race to the bottom where no discernible interstate externality exists are specious. While this argument has some merit, it is predicated on the assumption that citizens are immobile. This is a potentially dangcrous assumption. As explained above, citizens may move to jurisdictions that cause spillovers and away from jurisdictions that experience those spillovers. Thus, to the dcgree citizens are mobile, negative externalities may exacerbate regulatory races to the bottom. Id. at $1220 \mathrm{n} .25$. The true targets of Revesz's analysis are those who use the term "race to the bottom" recklessly to justify centralized power. This endeavor is worthwhile, but Revesz's attempts to treat the problem more finely may be an oversimplification.

182. For example, David Shapiro uses the race-to-the-bottom problem and negative externalities to justify weak judicial review for issues involving a balancing of state and federal power. See DAvID L. Shapiro, Federalism: a Dialogue (1995).

183. Shapiro does not discuss the possibility of using the existence of market imperfections as a standard for deciding the scope of centralized power and instead uses externalities solely as a justification for federal power that is not subject to judicial review. $I d$. at 42 ("The point is not that competition in the private sector is without economic value. But when market imperfections call for some regulatory action, soeial welfare is more likely to be maximized when such action is taken on a national level.").

184. Oliver Williamson did much of the pioneering work on the problems holdouts can pose, even though much of his professional work concentrated on vertical mergers. See OLIVER E. Williamson, MARKETS AND HIERARCHIES: ANALYSIS AND ANTITRUST IMPLICATIONS (1975). Robert Cooter also did some of the early work applying the concept of holdouts to legal contexts. See Robert Cooter, The Cost of Coase, 11 J. Legal Stud. 1 (1982). 
a given decision, there is an incentive for the last party to hold out for all of the surplus wealth created by the decision. For example, if the government needs five parcels of land to complete a road, absent the takings power it would be forced to reach agreement with the owners of all five parcels. Even if the government secured an arrangement with four of the landholders, the fifth might demand an exorbitant price and derail the project. Consequently, the problem of holdouts is a prominent justification for the Fifth Amendment takings power. ${ }^{185}$

In the context of federalism, holdouts can be a problem for any issue outside the purview of Congress's constitutional powers. ${ }^{186}$ In order to develop a uniform policy on a matter that Congress cannot regulate, all of the states must pass similar laws. ${ }^{187}$ When states are unable to pass uniform laws and can export harmful goods and activities, holdouts can cause acute market failure. Laws regulating gun sales are a good example. If a group of states wishes to curtail gun sales, the states may pass restrictions, such as background checks. However, a neighboring state may profit from relaxing its own gun laws in order to attract the gun sales that would otherwise take place in the more restrictive state. The holdout state with the relaxed rules essentially would export guns to neighboring states, frustrating the political preferences of the citizens who demanded the restrictive rules. Permitting more decentralized government can invite such holdouts and facilitate such negative spillovers.

A holdout will only facilitate spillovers, however, if that state can externalize the harm involved. A comparison of gambling laws and laws governing the drinking age will clarify this point. A state that permits gambling may encourage a significant degree of tourism. But the harm associated with gambling, usually thought to be an increase in crime, will be confined largely to the state that permits the gambling. Thus, so long as the benefits and burdens of regulation are internalized by a particular holdout state, its holding out causes little spillover to neighboring states. However, if the harm associated with an activity is experienced by neighboring states, spillovers pose a difficulty. For example, if one state permits drinking at an earlier age than neighboring states, it will experience an influx of people who would be underage in their home jurisdictions. The problem for the

185. See Robert CoOter \& Thomas Ulen, Law ANd Economics 164-65 (3d ed. 2000).

186. For a nuanced look at the intricate holdout problems posed by overlapping local, state, and federal authority, see Roderick M. Hills, Jr., The Political Economy of Cooperative Federalism: Why State Autonomy Makes Sense and "Dual Sovereignty" Doesn't, 96 MicH. L. Rev. 813, $875-86$ (1998). Hills makes an argument about the wisdom of two recent Tenth Amendment cases, New York v. United States, 505 U.S. 144 (1992), and Printz v. United States, 521 U.S. 898 (1997), that is in some respects similar to the argument made concerning Lopez in this Comment. Hills argues that while "the doctrine of state autonomy announced in New York and Printz makes good functional sense," the Court failed to articulate a "functional basis" or theory for these results. Hills, supra, at 938.

187. In contrast, at the federal level, lawmaking generally follows the median rule, where only a majority of representatives (as well as the executive) must approve the federal law. 
neighboring states is that these people may purchase the alcohol from the state with the more relaxed rule yet cause the harm associated with underage drinking, such as increased violence and driving under the influence, in their home states. In this situation, the state that permits the underage drinking exports the harm associated with the activity.

Leaving activities that create negative externalities and holdouts outside the ambit of the commerce power risks recreating the problems that spurred the Commerce Clause in the first place. States, understandably, can be expected to pursue the self-interest of their citizens. One can expect that states will take advantagc of opportunities to shunt the costs of externalities to a neighboring state or to profit by holding out on regulations. If Congress is unable to regulate an activity prone to externalities or holdouts, there is a risk that the costs of these activities will leave everyone worse off than they would be if Congress could set uniform policy.

\section{Political Market Failure and the Dormant Commerce Clause}

The same statc self-interest that underlies the collective action problems discussed above drives the Court's Dormant Commerce Clause jurisprudencc, which allows courts to strike down statutes that discriminate against interstate commerce. Under the Dormant Commerce Clause, courts use a three-prong standard to determine whether a state law is permissible. First, the state law must serve a legitimate state interest. ${ }^{188}$ Second, even if the statute addresses a legitimate state end, if it nonetheless discriminates against interstate commerce, it may be per se invalid. ${ }^{189}$ Finally, the law must not place a burden on interstate commerce that is "clearly excessive in relation to the putative local benefits." 190

The same skepticism regarding state political action that drives political market theory underlies Dormant Commerce Clause doctrine. Laurence Tribe explains this standard of exceedingly strict review of state laws by noting that Dormant Commerce Clause doctrine "underscore[s] the recognition implicit in the Commerce Clause that state and local lawmakers are especially susceptible to pressures that may lead them to make decisions harmful to the commercial and other interests of those who are not constituents of their political subdivisions."191

The same skcpticism of state political actors that justifies use of the Dormant Commerce Clause to strike down state statutes, even when Congress has the ability to preempt those state statutes, can justify using the Commerce Clause to prevent externality and holdout problems. Extending

188. See TribE, supra note 30, § 6-5, at 1050 (citing Edgar v. MITE Corp., 457 U.S. 624, 644 (1982)).

189. Id. (citing Or. Wastc Sys., Inc. v. Dep't of Envtl. Quality, 511 U.S. 93, 99 (1994)).

190. Id. at 1050-51 (quoting Pike v. Bruce Church, Inc., 397 U.S. 137, 142 (1970)).

191. Id. at 1051 . 
this skepticism to the Commerce Clause proper would both give a stronger theoretical grounding to Commerce Clause jurisprudence and harmonize two bodies of law derived from the same clause of the Constitution. One might find reasons to justify variable treatment of the Dormant Commerce Clause and the Commerce Clause proper. However, the possible justifications for treating these doctrines so differently are ultimately unsatisfying.

Perhaps the best argument for the variation in these bodies of law is that the Dormant Commerce Clause targets commercial activity, which is undoubtedly within the scope of the commerce power, while the approach to the Commerce Clause advocated in this Comment targets some activity that is arguably noncommercial. While this distinction has some merit as a means of justifying different modes of analysis under the Dormant Commerce Clause and the Commerce Clause proper, it is unsatisfying because it relies on a semantic dichotomy that has little theoretical justification. A pressing problem with the economic-noneconomic distinction that demarcates the boundary of the commerce power in the post-Lopez world is that it provides little theoretical guidance for courts deciding cases that are on the margin of the distinction. Under Lopez, courts deciding such cases presumably have to determine how many inferences are necessary to characterize the activity at issue as substantially affecting interstate commerce. ${ }^{192}$ This determination is difficult because the economic-noneconomic distinction is a new framework for Commerce Clause analysis, so there is little precedent to help determine what types of activities are economic in nature. In contrast, incorporating a theoretical rationale, such as the one advocated in this Comment, into Commerce Clause jurisprudence provides courts and statute drafters more guidance on the scope of the commerce power. For example, some environmental regulations, such as the filling regulations at issue in Solid Waste, involve activity that may or may not be economic. ${ }^{193}$ Nevertheless, because such an activity clearly implicates externalities, it is properly within the scope of the commerce power under the theory proposed in this Comment. By recognizing the prevention of holdouts and extcrnalities as a legitimate goal of the Commerce Clause, the Court would prevent some of the indeterminacy facing courts and statute drafters confronted with an activity that is not clearly economic. Granted, almost any legal standard will leave room for some amount of indeterminacy, but

192. The Lopez opinion criticizes the Government's arguments for upholding the GFSZA because it requires "pil[ingl inference upon inference in a manner that would bid fair to convert congressional authority under the Commerce Power to a general police power of the sort retained by the States." United States v. Lopez, 514 U.S. 549, 567 (1995). The Court, however, provides little guidance on how many or how large inferences must be before a statute or regulation runs afoul of the Commerce Clause. The dearth of Commerce Clause cases decided by the Court since Lopez means that courts and statute drafters still have little guidance on the outer boundary of the commerce power.

193. Solid Waste Agency v. United States Army Corps of Eng'rs, 531 U.S. 159 (2001). 
those that have theoretical grounding are almost sure to provide a stronger basis for deciding close cases.

Dormant Commerce Clause doctrine is theoretically grounded insofar as it is based on skepticism of state actors. This baseline purpose allows courts to look for indicia of states' shunting costs to other states in cases on the borders of the legal doctrine governing the Dormant Commerce Clause. ${ }^{194}$ Commerce Clause doctrine could benefit from a similar theoretical grounding, such as that advocated by this Comment. In addition to the depth that a political market failure theory provides, this approach would help to harmonize two bodies of law based in the same clause of the Constitution. The next section discusses the questions left open by the Lopez standard and discusses how a political market theory could answer some of those questions.

\section{Regulatory Warfare as a Holdout Problem}

Rent extraction, the problem that gave rise to the Commerce Clause, is a variation on the race-to-the-bottom theme. The Articles of Confederation did not sufficiently address states' attempts to extract rents, primarily in the form of duties on goods in transit. ${ }^{195}$ Writings by the Framers make clear that one of the primary purposes of the interstate Commerce Clause was to put an end to individual states' collection of duties on commerce that moved through their territories. ${ }^{196}$

The Framers essentially aimed to offer a solution to a collective action problem. If a party shipping goods from State $\mathrm{A}$ to State $\mathrm{C}$ has to go through State B en route, State B would have everything to gain and nothing to lose by imposing a tax on those goods, so long as the goods were not being sold to the residents of State B. ${ }^{197}$ In much the same manner, other states would be willing to impose taxes on goods coming from or going to State B. This is the essence of the collective action problem known as the prisoner's dilemma. ${ }^{198}$ In the rent-extraction situation, as in the regulatory

194. Kassel v. Consolidated Freightways Corp., 450 U.S. 662 (1981), is an example of the use of such indicia. The case involved an lowa law prohibiting the use of 65-foot double trucks on Iowa roadways. In a plurality opinion striking down this law, Justice Powell cited a statement by the lowa governor attesting to the small benefits to Iowa citizens and the large benefits to out-of-state citizens that one version of the law would provide. Id. at 677 .

195. See Nelson \& Pushaw, supra note 13, at 22-24.

196. See supra note 20 and accompanying text.

197. In such a case, there might be some reticence to tax the goods because this decision could curtail the flow of goods into State B. However, because Statc B does not benefit from the goods, State $B$ can extract rents while the goods are in transit.

198. The prisoner's dilemma refers to a situation in which the players of a game would be better off cooperating but have individual incentives not to cooperate. For a helpful overview of the history and technical aspects of the prisoner's dilemma, see, for example, Neil S. Siegel, Comment, State Sovereign Immunity and Stare Decisis: Solving the Prisoner's Dilemma Within the Court, 89 CALIF. L. REv. 1165, 1172-79 (2001). The problem takes its name from a scenario in which two criminals who have collaborated in a crime are both detained. The best outcome from each criminal's perspective is to 
race to the bottom, the collective suffers if states pursue their self-interest. If a central body exists to restrain the states' ability to extract rents, every actor will be in a better position because the ability to tax goods in transit will be attenuated, if not eliminated.

The Framers noticed both the problem created by decentralized control of tax policy and the solution of placing an increased power of interstate regulation in the hands of the centralized government. ${ }^{199}$ Whereas the Court has been eager to eliminate rent extraction by the states under the Dormant Commerce Clause, it has generally ignored the possibility of using the Commerce Clause to correct similar collective action problems posed by negative externalities and holdouts. This dichotomy makes little sense, because these collective action problems, at least in part, gave rise to the Commerce Clause in the first place. The next Part analyzes the insensitivity of the Lopez standard to these collective-action problems and suggests the beginnings of a solution to this deficiency.

\section{IV}

\section{Political Market Failure Theory Applied to the Commerce Clause}

This Part first applies the implications of political market failure theory to the standard articulated by the Court in Lopez. ${ }^{200}$ The primary problem with the Lopez standard is that it may not allow congressional regulation of activities that are prone to political market failure. To demonstrate the application of a Commerce Clause standard based on political market failure, this Part also analyzes the activities at issue in the Court's recent decisions in Jones v. United States ${ }^{201}$ and Solid Waste Agency $v$. United States Army Corps of Engineers. ${ }^{202}$ This analysis demonstrates that while the activities at issue in both cases may be invalid exercises of the commerce power under Lopez, the activity in Solid Waste is prone to political market failure, so there is a strong argument for including it within the scope of the Commerce Clause.

confess while the other remains silent beeause this will result in the lightest sentence for the confessor. This situation creates an incentive for both criminals to confess. If neither had confessed, however, both would be better off in sentencing terms. The interstate tariff situation is analogous. Any given state is better off if it is the only state that imposes tariffs on interstate commerce. This situation will lead all states to impose tariffs. All states would be better off if none imposed tariffs, but the collective action problem prevents this solution. Similarly, any given state would prefer that all others curtail activities that impose externalities. The prisoner's dilemma incentive structure leads many statcs to pass permissive laws when all would be better off with more restrictive laws.

199. The Madison and Hamilton passages from THE FEDERALIST cited in Part 1.A demonstrate the Framers' fears of excessively decentralized commerce regulation. See Nelson \& Pushaw, supra note 13 , at 25 . See also supra notes 20,23 and accompanying tcxt.

200. United States v. Lopez, 514 U.S. 549 (1995).

201. 529 U.S. $848(2000)$.

202. 531 U.S. $159(2001)$. 


\section{A. The Infirmities of Lopez}

The most dramatic change made by the Court in Lopez was to limit the reach of the substantial effects test. To survive scrutiny under the Commerce Clause after Lopez, a federal statute must address an activity that is economic in nature or contain a jurisdictional element that ensures that only activities with an interstate character are regulated. ${ }^{203}$ One problem with this standard is that it is not sufficiently sensitive to political market failure. A better inquiry, sensitive to political market failure concerns, would determine whether the benefits and burdens associated with a given activity tend to take place within the borders of a given jurisdiction.

In many situations, activities that are prone to producing spillovers will have a sufficiently economic character to permit federal regulation under thc Lopez standard. Industrial pollution is one example. Because not all benefits and burdens are economic in nature, however, in some instances the Lopez test will not permit federal jurisdiction even though the theory of political market failure suggests that centralized regulation would be appropriate. The activity at issue in Solid Waste, for instance, was not clearly economic in nature but has discernible interstate effects. ${ }^{204}$ In other words, it implicates political market failure. Although this activity would be outside the scope of the commerce power under Lopez, fidelity to the original purpose of the Commerce Clause, as well as wise policy, requires that Congress have the ability to regulate the behavior at issue.

Additionally, relying on the Lopez standard often will permit decentralized governance when there is no compelling rationale for centralization. Indeed, under the theory of political market failure, the outcome reached by the Court in Lopez appears to be correct. Political preferences with respect to guns vary widely across the country. Satisfying these varied preferences, as well as determining the optimal means for governing problems posed by guns, therefore, requires different rules across jurisdictions. Demonstrable problems with spillovers would provide a reason to preempt local and state regulation of guns. But the particular problem addressed by the statute in Lopez did not seem to involve existing spillovers. ${ }^{205}$

203. United States v. Lopez, 514 U.S. 549, 559-62 (1995).

204. Solid Waste Agency v. United States Army Corps of Eng'rs, 531 U.S. 159 (2001). See infra Part IV.C.

205. In his Lopez dissent, Justice Breyer includes a lengthy appendix, which he claims shows that guns in schools may have an effect on interstate commerce. Lopez, 514 U.S. at 618-23 (Brcyer, J., dissenting). However, Justice Breyer's appendix does not demonstrate that the Lopez decision will create discernible spillover effects for two reasons. First, in the wake of Lopez, a state or municipality is free to pass stronger legislation than the GFSZA. Second, even if a jurisdiction has less stringent school-zone gun laws than the GFSZA, the Breyer appendix demonstrates only the hypothetical effeets at the far margins of the activity. The detrimental impact on education will occur largely in the jurisdiction with the lax gun law. As this Comment argues, discernible spillover effects must exist or be likely in order to form a compelling rationale for exercise of the commerce power over a particular activity or issue. 
Permitting Congress to pass a uniform rule governing guns in school zones undercuts the satisfaction of the varying political preferences for regulating guns near schools and undermines policy experimentation on this issue.

\section{B. Jones v. United States}

In cases subsequent to Lopez, the Court has foregone opportunities to refine the Lopez standard in a manner consistent with the theory of political market failure. ${ }^{206}$ In Jones $v$. United States, ${ }^{207}$ the Court addressed 18 U.S.C. $\S 844$ (i), which makes it a federal crime to damage or destroy, "by means of fire or an explosive, any ... property used in interstate or foreign commerce or in any activity affecting interstate or foreign commerce." ${ }^{208}$ The petitioner in Jones had thrown a Molotov cocktail through the window of a private residence and subsequently was indicted and convicted under, inter alia, $\S 844(i){ }^{209}$ The petitioner argued that the application of $\S 844$ (i) to his conduct exceeded Congress's authority under the Commerce Clause. ${ }^{210}$ This case thus presented the Court with an opportunity to clarify the reach of the Lopez rationale. In an earlier case, Russell v. United States, the Court had held that arson against a rental property properly triggered $\S 844(\mathrm{i}){ }^{211}$ Lopez seemed to create some question whether the arson of a piece of rental property substantially affected interstate commerce. The Court, however, unanimously disposed of the case through a narrowing interpretation of the statute instead of addressing the constitutionality of $\S 844(i) .{ }^{212}$

Applying the Lopez standard to the fact pattern in Jones demonstrates some of the potential ambiguities in the Lopez economic-noneconomic distinction. To survive scrutiny under the third prong of the Lopez test, a statute must regulate an economic activity affecting interstate commerce. ${ }^{213}$

206. The majority in United States v. Morrison, 529 U.S. 598 (2000), simply applied the Lopez standard without significantly revisiting its justifications. See discussion infra Part II.B.6.

207. Jones, 529 U.S. $848(2000)$.

208. 18 U.S.C. $\S 844(i)$ (Supp. IV 1994).

209. Jones, 529 U.S. at 851 .

210. Id. at $851-52$.

211. 471 U.S. 858 (1985) (holding that rental properties affect commerce and thus fall within the scope of $\S 844(\mathrm{i}))$.

212. Jones, 529 U.S. at 857-59. The Court invoked the canon of construing statutes to avoid constitutional questions. This canon has been heavily criticized. See, e.g., Henry J. FriendLY, Mr. Justice Frankfurter and the Reading of Statutes, in BENCHMARKs 196, 211-12 (1967) ("[This rule, whether it be denominated one of statutory interpretation or, more accurately, of constitutional adjudication-still more accurately, of constitutional nonadjudication-is likely to bccome one of evisceration and tergiversation."). Judge Posner is also a critic of the canon. Richard A. Posner, The Federal Courts: Crisis And Reform 285 (1985) (arguing that the canon creates tension between the judiciary and the majoritarian branches of government). For more recent commentary, sec Frederick Schauer, Ashwander Revisited, 1995 SuP. CT. Rev. 71; Adrian Vermeule, Saving Constructions, 85 Geo. L.J. 1945 (1997); Erncst A. Young, Constitutional Avoidance, Resistance Norms, and the Preservation of Judicial Review, 78 Tex. L. Rev. 1549 (2000).

213. United States v. Lopez, 514 U.S. at 559-60. 
But due to the dearth of case law interpreting Lopez, it remains unclear whether both the criminal aet (arson) and the target of the act (the property) must have an economic character or whether it is sufficient for either the act or the target to possess this economic character. If the latter is the case, application of the statute to arson of a passenger plane might survive scrutiny under the Lopez standard, because planes have an economic character and are used in the channels of interstate commerce. But if the former is the case, the statute would not survive scrutiny because arson does not have a commercial quality and does not appear to be an economic activity. Because Lopez does not provide an underlying theory to justify the economic-noneconomic distinction, there is little to guide resolution of this ambiguity. ${ }^{214}$ Like the earlier commerce-manufacturing distinction, the standard eannot account for a number of hybrid cases. Because there is little theory underlying this distinction beyond a commitment to federalism,

214. The Court recently employed the economic-noneconomic distinction in Citizens Bank $v$. Alafabco, Inc., 123 S. Ct. 2037 (2003) (per curiam). This case concerned a debt-restructuring agreement that resulted in substantial litigation. $I d$. at 2038-39. The Citizens Bank attempted to compel arbitration under the Federal Arbitration Act (FAA). Id. at 2039. The Supreme Court of Alabama held that, because the debt-restructuring agreement did not have a substantial effect on interstate commerce, the FAA did not govern the dispute. Id.

The Supreme Court reversed, applying an aggregation analysis to determine that the debt transaction was within the scope of the commerce power. Id. at 2040 ("This case is well within our previous pronouncements on the extent of Congress' Commerce Clause power."). Curiously, the Court appears to cabin the use of aggregation analysis to economic activity, stating that "Congress' Commerce Clause power 'may be exercised in individual cases without showing any specific effect upon interstate commerce' if in the aggregate the economic activity in question would represent 'a general practice ... subject to federal control." Id (quoting Mandeville Island Farms, Inc. v. Am. Crystal Sugar Co., 334 U.S. 219, 236 (1948)).

This statement is curious because once one characterizes an activity as economic, the aggregation analysis seems redundant. Chief Justice Rehnquist distinguished the situation in Lopez from that in Wickard, 317 U.S. 111 (1942), by saying that Wickard "involved economic activity in a way that the possession of a gun in a school zone does not." Lopez, 514 U.S. at 560 . If a transaction involves economic activity, is there any doubt that the activity, when aggregated, will have interstate effects? It is unclear why the Court feels the need to engage in the aggregation analysis when it seems that the characterization of an activity as economic inevitably leads to a conclusion that the activity has an interstate character. Cases addressing laws that regulate economic activity, such as Perez $v$. United States, 402 U.S. 146 (1971), Katzenbach v. McClung, 379 U.S. 294 (1964), and Heart of Atlanta Motel, Inc. v. United States, 379 U.S. 241 (1964), find those laws to be within the scope of the commerce power, while cases addressing laws that do not regulate economic activity, such as Lopez and United States v. Morrison, 529 U.S. 598 (2000), find those laws to be outside the commerce power.

The more pressing question is whether an aggregation analysis is permissible in cases that are not clearly economic in nature. One main argument of this Comment is that some activities that are arguably noneconomic (such as those at issue in Solid Waste, 532 U.S. 159 (2001)) should be within the scope of the commerce power. It is necessary to aggregate the effects of these activities to determine whether a state is externalizing harm stemming from the aetivity. If the Court really means to limit the aggregation analysis solely to economic activities, as the opinion in Citizens Bank seems to suggest, its position is problematic in two ways. First, it makes aggregation analysis redundant for the reasons addressed above. Second, it undermines one of the original purposes of thc Commerce Clause by allowing states more latitude to externalize harms when they involve noneconomic activity. 
there is little to guide the Court's reasoning in cases that implicate this ambiguity.

An analysis based on a theory of political market failure avoids these problems. Analyzing the potential for political market failure in the Jones context requires examining the benefits and burdens associated with arson and with laws that criminalize arson. It seems clear that arson does not impose a discernible negative externality on neighboring jurisdictions, particularly at the state level. Criminal arson usually occurs in a circumscribed area and is probably rarely intended to create harm that spills over jurisdictional lines. The discernible costs of arson therefore tend to be localized to the jurisdiction where the arson occurs. Likewise, a state or jurisdiction holding out on arson laws would not profit by doing so. A state cannot export the harm associated with arson as it can export the harms caused by less restrictive handgun or alcohol laws. Consequently, a state will gain little by passing a relaxed arson law. Given the lack of any colorable concern about spillovers and holdouts, there is no strong rationale for centralized regulation of arson under a theory of political market failure..$^{215}$ Moreover, allowing each jurisdiction to customize its arson laws will better satisfy the political preferences of citizens in different jurisdictions and will likely be more closely tailored to the needs and circumstances of particular jurisdictions.

\section{Solid Waste Agency v. United States Army Corps of Engineers}

In Solid Waste Agency v. United States Army Corps of Engineers, the Court faced another situation potentially implicating the Lopez standard, but the Court again decided the issue on statutory grounds instead of engaging the constitutional dilemma. ${ }^{216}$ In this case, however, unlike in Jones, ${ }^{217}$ the Court split five to four, along the same lines as in Lopez. ${ }^{218}$

215. One argument against decentralization is that a national rule or policy permits economies of scale. See, e.g., Jacques LeBoeuf, The Economics of Federalism and the Proper Scope of the Federal Commerce Power, 31 San Diego L. Rev. 555, 565-67 (1994). An example sometimes mentioned is space programs. It is much more economical to have one national space program than to have each state separately carrying out redundant research on space. This argument is strongest where the scale of an enterprise is quite large and requires significant coordination. For example, there may be economies of scale to criminalizing and prosecuting organized crime syndicates that have significant interstate operations. Such a policy concern could, for example, justify the passage of federal laws such as the Racketeer Influenced and Corrupt Organizations Act. Economies of scale, however, are not a concern for the crime at issue in Jones. The savings in transaction costs resulting from coordinating the criminalization of arsons are not likely to outweigh the benefits of taking an individualized approach to the crime in each jurisdiction. Moreover, because arson lacks any significant interstate character, in the sense that there are likely few organized groups propagating interstate arson, using national resources to prosecute arsons will likely not result in economies of scale.

216. 531 U.S. $159(2001)$.

217. 529 U.S. $848(2000)$.

218. 514 U.S. 549 (I995) 
Solid Waste involved the Army Corps of Engineers' interpretation of $\S 404(a)$ of the Clean Water Act. ${ }^{219}$ Section 404(a) regulates the filling or dredging of material into "navigable waters." ${ }^{220}$ The Army Corps of Engineers (the "Corps") interpreted this language to provide for federal authority over a sand and gravel pit that served as a habitat for migratory birds. ${ }^{221}$ Thus, the case presented two issues: (1) Was the extension of federal authority over the land at issue a permissible statutory interpretation of $\S 404(a)$ ? (2) If so, does Congress have the power under the Commerce Clause to exercise this authority? ? $^{222}$

In 1986, the Corps issued a ruling to clarify its jurisdiction under $\S 404(a) .{ }^{223}$ The ruling included a guideline called the "migratory bird rule," specifying that $\S 404$ (a) extended to intrastate waters "[w]hich are or would be used as habitat by other migratory birds which cross state lines." 224 Writing for the majority in Solid Waste, Chief Justice Rehnquist concluded that this rule was an unreasonable interpretation of the "navigable waters" language in $\S 404(a)^{225}$ and thus not entitled to deference under the rule of Chevron U.S.A., Inc. v. Natural Resources Defense Council, Inc. ${ }^{226}$ Because it found the Corps' interpretation unreasonable, the Court did not have to address the difficult question of whcther the migratory bird rule falls within the scope of the commercc power. ${ }^{227}$ While there may be an institutional rationalc for avoiding this issue, ${ }^{228}$ the constitutional

219. 33 U.S.C. § 1344(a) (2000).

220. $I d$.

221. Solid Waste, 531 U.S. at 162.

222. Id.

223. Id. at 164.

224. Id. (quoting 51 Fed. Reg. 41,217 (Nov. 13, 1986)).

225. Id. at 166-74. The Court gave four primary reasons for not deferring to the Corps' interpretation. First, the Court distinguished the character of the body of water at issue in Solid Waste from that of the body of water at issue in United States v. Riverside Bayview Homes, Inc., 474 U.S. 121 (1985) (holding that $\S 404$ (a) did provide jurisdiction to the Corps over wetlands abutting navigable waterways). Solid Waste, 531 U.S. at 167-68. Second, the Court found that Congress's failure to approve a proposed modification to $\S 404$ (a) in 1977 was not sufficient evidence of congressional acquiescence to the expansive Corps interpretation of $\S 404$ (a) in place at the time. Id. at 169-71. Third, the Court rejected the Corps' argument that an exeeption in $\S 404(\mathrm{~g})$ permitting regulation of "other ... waters" was broad enough to include the nonnavigable, isolated area at issue. Id. at 171-72. Finally, the Court found that the language at issue was too ambiguous to satisfy the clear statement required when Congress acts at the boundary of its Constitutional power. Id. at 172-74 (citing Edward J. DeBartolo Corp. v. Fla. Gulf Coast Bldg. \& Constr. Trades Council, 485 U.S. 568, 575 (1988)).

226. 467 U.S. 837 (1984).

227. Solid Waste, 531 U.S. at $172-74$ (citing Edward J. DeBartolo Corp. v. Fla. Gulf Coast Bldg. \& Constr. Trades Council, 485 U.S. 568, 575 (1988)).

228. The rule of avoiding constitutional questions when there are statutory grounds for doing so is sometimes seen as a means of protecting the institutional capital of the Court in the Bickelian tradition. See BiCKEL, supra note 127. As a countermajoritarian institution, the Court does less damage by deciding an issue on statutory grounds, because this allows Congress to pass another statute to clarify the issue. By deciding an issue on eonstitutional grounds, the Court prevents Congress from passing subsequent legislation. See supra note 127. See also Lyng v. N.W. Indian Cemetery Protective Ass'n, 485 U.S. 439, 445 (1988) ("A fundamental and longstanding principle of judicial restraint requires that 
question presented by Solid Waste provided yet another opportunity for the Court to clarify the Lopez standard by using the insights of political market failure.

Solid Waste provoked a vigorous dissent by Justice Stevens, who, unlike the majority, chose to engage the constitutional question. His dissent is quite interesting because it invokes the race-to-the-bottom problem, which implicates the theory of political market failure. Stevens makes an elaborate series of arguments largely based on the legislative history of the Clean Water Act and contesting the majority's interpretation of $\S 404(a) .{ }^{229}$ After concluding that the majority's interpretation of $\S 404(a)$ is "miserly,"230 Justice Stevens considers whether the Corps' exercise of jurisdiction over the ponds was permissible under the Commerce Clause. ${ }^{231}$

Citing the Lopez standard, Justice Stevens first concludes that, in order for the regulation to survive scrutiny under Lopez, the regulated activity, discharging fill into a non-navigable pond, must "substantially affect" interstate commerce. ${ }^{232}$ In his view, discharging fill is a candidate for aggregation analysis and, when considered in the aggregate, falls within the scope of the commerce power. ${ }^{233}$

Justice Stevens produces three justifications for his conclusion that the activity at issue in Solid Waste, when considered in the aggregate, falls within the scope of the commerce power. First, he argues that discharging fill is an economic activity and as such satisfies the substantial effects prong of the Lopez standard. ${ }^{234}$ Justice Stevens next argues that the filling of the isolated ponds at issue in Solid Waste was causally connected to commercial activity because such ponds provide habitats for migratory

courts avoid reaching constitutional questions in advance of the nccessity of deciding thcm."); Rescue Army v. Mun. Ct., 331 U.S. 549, 569 (1947) ("constitutional issues ... will not be determincd ... in broader terms than are required by the precise facts to which the ruling is to be applied"); Ashwander v. Tenn. Valley Auth., 297 U.S. 288 (1936).

229. Solid Waste, 531 U.S. at 174-92 (Stevens, J., dissenting). Among Justice Stevens's more intcresting findings is a portion of the conference report for the Clean Water Act specifying that the "navigable waters" language was to "be given the broadest possible constitutional interpretation." Id. at 181 (quoting S. Conf. ReP. No. 92-1236, at 144 (1972)).

230. Id. at 192.

231. Id. at 192-97.

232. Id. at 192-93 (citing United States v. Lopez, 514 U.S. 549, 558-59 (1995)).

233. Solid Waste, 531 U.S. at 193 (Stevens, J., dissenting) (citing Perez v. United States, 402 U.S. 146, 153 (1971); Wickard v. Filburn, 317 U.S. 111, 127-28 (1942)).

234. Solid Waste, 531 U.S. at 193-94. This application of the economic-noneconomic distinction does little to support Stevens's argument, however, and instcad demonstrates the problems with the distinction. As predicted by Justice Breyer in his Lopez dissent, the distinction provides an ambiguous boundary for the scope of the commerce power. The distinction also, as noted above, lacks specificity with respect to what, exactly, must have an economic character. It could be the activity being regulated, in this ease the filling of ponds and swamps, or the targets of the activity, in this case the ponds and swamps themselves. 
birds, which in turn stimulate commercial activity through "bird watching and hunting." 235

Justice Stevens's final argument resonates with the theory of political market failure advocated by this Comment. Referring to the race to the bottom in concluding that the filling activity at issue in Solid Waste is a national rather than a local problem, ${ }^{236}$ Justice Stevens notes that filling ponds used by migratory birds can inflict externalities on other states. ${ }^{237}$ To support this proposition, he cites the Revesz article discussed above ${ }^{238}$ for the argument that the existence of externalities provides a policy rationale for federal jurisdiction. ${ }^{239}$ Although the dissent devotes little space to this argument, a more thorough analysis of the problem suggests that commerce power doctrine based on a theory of political market failurc would support a finding that the migratory bird rule falls within the scope of the Commerce Clause.

The key question for an analysis based on market failure is whether the benefits and costs of a given activity are largely internalized by a single jurisdiction. The benefits of permitting the discharge of fill into ponds are reasonably clear. By allowing this activity, a jurisdiction can generate the revenue and employment associated with the filling. Most of these benefits will be experienced within the jurisdiction. Therc seem to be few or no positive externalities associated with the filling activity. In contrast, thcre are strong reasons for suspecting that the filling activity may impose negative externalities on neighboring jurisdictions. The interdependence of ecosystems means that destroying habitat in one place can have dramatic effects in anothcr. While pollution of a navigable waterway would likely

235. Id. at 195. Citing studies by the Office of Technology Assessment, Justice Stevens argues that the connection between filling ponds and commerce is "direct and concrete," $i d$., and that this connection satisfies the guideline articulated in United States v. Morrison, 529 U.S. 598, 612 (2000), in whieh the Court had suggested that Congress may not regulate an activity when the connection between the activity and commerce is "attenuated." The studies Stevens cites, however, speak only to the amount of commerce generated by hunting and bird watching and do not quantify the connection between commerce and the specific filling at issue. Moreover, Justice Stevens does not base his conclusion on any standard distinguishing concrete from attenuated relationships. Given his finding that the connection in Solid Waste was direct and concrete, his definition of this standard appears to boil down to the nonjusticiability argument advocated by proponents of the political safeguards thesis and suggested by his Lopez dissent. Lopez, 514 U.S. 549, 602-03 (Stevens, J., dissenting).

236. Solid Waste, 531 U.S. 159, 195-96 (Stevens, J., dissenting) (suggesting that Congress cannot pass legislation that blurs the distinction "between what is truly national and what is truly local" (quoting Morrison, 529 U.S. at 617-18)).

237. Solid Waste, 531 U.S. at 195-96 (Stevens, J., dissenting).

238. See Revesz, supra note 180.

239. Solid Waste, 531 U.S. at 195-96 (Stevens, J., dissenting). Given the small amount of space dedicated to the externality argument, it is not surprising that the dissent gives short shrift to the arguments made by the subtle, nuanced approach of Revesz. See supra notes 180-81 and accompanying text. In particular, the Solid Waste dissent ignores Revesz's argument that one must carefully inquire whether state regulation is insufficient to deal with an environmental issue before advocating federal power over the issue. 
impose a greater negative externality on neighboring jurisdictions, destroying the habitat of the migratory birds that used the navigable waterway at issue in Solid Waste eould still have created significant environmental damage in neighboring jurisdictions. ${ }^{240}$

This possibility of negative externalities also suggests a potential holdout problem where federal jurisdiction over filling activity is prevented. Absent complete centralized authority over filling activity affecting the ecosystems of a cluster of jurisdictions, the health of the ecosystem will depend on how strongly each jurisdiction regulates filling activity. A jurisdiction that values the ecosystem highly for either commercial or aesthetic reasons is likely to pass relatively strict laws regulating filling. However, as more jurisdictions pass restrictive filling laws, the temptation for a jurisdiction to hold out by relaxing filling laws becomes more acute. This temptation will be especially strong if all jurisdictions but one have very restrictive laws; the permissive jurisdiction will be in a monopoly position and can charge higher filling fees accordingly. If the harm from filling is internalized by the permissive district, the costs and benefits from the activity are wholly internalized to the district, and citizens of that district may make political choices based on the sum totals of those costs and benefits. However, if the permissive jurisdiction is exporting harm in the form of damage to neighboring ecosystems, the jurisdiction may have an incentive to keep laws permissive or to make them more permissive in order to retain the benefits of permissive laws while experiencing only some of the harm they produce.

This potential for negative externalities and holdouts with respect to filling activity suggests that there may be reason to allow federal jurisdiction over the matter. The inquiry into whether the extent of an externality warrants the exercise of federal control is fact-intensive and requires a substantial degree of expert knowledge. When possible, it is probably more desirable to permit an agency, which is a repository of expertise, to make this inquiry. Because courts are not the ideal forum for such an inquiry, the element of the Lopez standard allowing exercise of the commerce power when the regulated activity involves an interstate component will sometimes be an inadequate and overly restrictive means of governing the proper scope of the commerce power. ${ }^{241}$

240. The majority opinion in Solid Waste seemed to miss the potential for harm to spill beyond the boundaries of a locality. Chief Justice Rehnquist insisted that land-use regulation is a state and local concern. Solid Waste, 531 U.S. at 174 (citing Hess v. Port Authority Trans-Hudson Corp., 513 U.S. 30, 44 (1994)). In cases where there is potential for spillovers to other jurisdictions, as in Solid Waste, this claim is suspect.

241. This analysis applies only to the constitutional question in Solid Waste, which the majority chose not to address. The statutory question-whether Congress delegated this power to the Corps-is a perfectly appropriate question for a court to answer, but its proper resolution is outside the scope of this Comment. 


\section{CONCLUSION}

The Lopez standard is unlikely to give Congress jurisdiction that is overly broad by the standards of a theory of political market failure. Application of the Lopez standard in a case like Jones, where the theory of political market failure counsels against giving Congress jurisdiction over arson laws, would produce a result that concords with the theory of political market failure. The more pressing concern is that the Lopez standard will not permit congressional jurisdiction when there are strong reasons for allowing a uniform federal rule. Solid Waste demonstrates this danger. The lack of any clear connection between the filling activity at issue in the case and economic behavior means that the filling activity might fail the Lopez substantial effects test. Commerce Clause doctrine based on a theory of political market failure would question this result given the potential for negative externalities and holdouts inherent in this type of activity.

Not all problems posed by negative externalities and holdouts warrant federal jurisdiction-the magnitude of each problem should, of course, play a role. Nevertheless, the Court's ambiguous approach to Commerce Clause jurisdiction could benefit from an analysis that takes into account the existence of or potential for political market failure. This analysis is not only sound policy but also effectuates the original purpose of the Commerce Clause: preventing the type of unceasing animosities between the states that obstruct the public tranquility of the entire nation. 